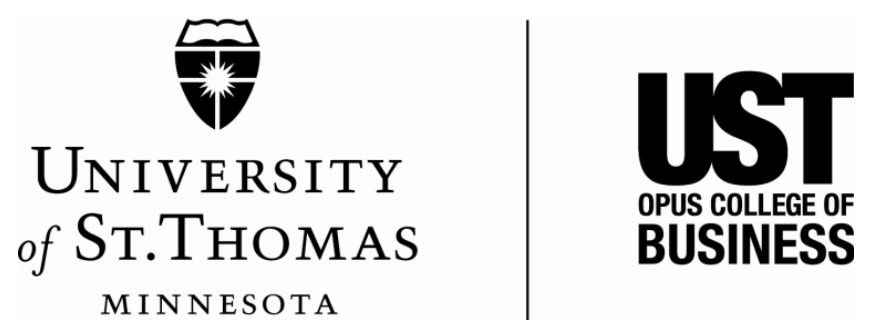

\title{
The Effect of New Jersey Lottery Promotions on Consumer Demand and State Profits
}

Kathryn L. Combs, Jocelyn Elise Crowley, and John A. Spry Working Paper

Copyright (C 2013 by Kathryn L. Combs, Jocelyn Elise Crowley, and John A. Spry. All rights reserved. Do not quote or cite without permission from the authors.

Working papers are in draft form. This working paper is distributed for purposes of comment and discussion only. Its contents should be considered to be preliminary and may not be reproduced without permission of the copyright holder 


\title{
The Effect of New Jersey Lottery Promotions on Consumer Demand and State Profits
}

\author{
Kathryn L. Combs, Jocelyn Elise Crowley, and John A. Spry*
}

February 2013

\begin{abstract}
We estimate elasticities of demand for New Jersey's Pick 3 and Pick 4 midday/evening numbers games by exploiting random price variation generated by episodic promotions for each game. These Pick 3 Green Ball and Pick 4 Red Ball promotions lower the price of a lottery ticket for an evening numbers game by increasing prize payments during the 28-day promotion periods. The own-price elasticity of demand for the evening Pick 3 and Pick 4 games are both approximately -0.5 . During the promotions, the loss in margin outweighs the gain in sales because of this inelastic demand. However, Green Ball promotions increase state profits by about $\$ 14.5$ million because of the increase in sales of Pick 3/Pick 4 games and instant games after the promotion ends, and because of the complementarity of Pick 3 with Pick 4 and instant games during the promotion. Red Ball promotions reduce state profits by an estimated $\$ 2.6$ million because increased evening Pick 4 sales after the promotion ends are not sufficient to offset the losses during the promotion, and the Pick 4 promotion has a net negative effect on other lottery games. (JEL D12, H71, L83, L98)
\end{abstract}

Keywords: Lottery, Gambling, Price Elasticity, Policy Evaluation

Preliminary draft. Please do not cite without permission.

*Combs and Spry: Finance Department, University of St. Thomas, St. Paul/Minneapolis, MN Crowley: Public Policy Program, Edward J. Bloustein School of Planning and Public Policy, Rutgers, The State University of New Jersey 


\section{INTRODUCTION}

State governments need to understand the factors that drive lottery ticket sales as they attempt to increase lottery profits. These profits are often critical to funding important programs, like education [Matheson and Grote 2008]. One key variable that affects sales is the implicit price of a lottery ticket or the expected loss to a lottery consumer. Knowledge of price elasticities that link these prices to the volume of tickets sold should therefore be an important part of state lotteries' profit maximization plans. While there has been work on large-jackpot, lotto-type games, there has been little research estimating price elasticities for daily numbers games because variation in the odds and prices of these products is rare. The odds of lottery games tend to remain largely stable for prospective players over the lives of these games. In addressing this identification challenge, economists have used multiple means of determining price effects, such as studying changes in lottery design features over long periods of time or exploiting differences in the operational management of games that run across lottery jurisdictions [Beenstock et al. 2000; DeBoer 1986; Vrooman 1976]. The central problem with some of these studies, however, is that the design changes might be endogenous to the games themselves, such as when policymakers institute rule modifications due to flagging sales.

By far the most promising source of price variation that has been utilized by economists to estimate these elasticities without the confounding bias of potential endogeneity has been the use of lottery jackpot rollovers [Cook and Clotfelter 1993; Gulley and Scott 1993]. Briefly stated, in some lottery games when there are no winners, the jackpot is "rolled over" into the next drawing's winnings. These jackpot rollovers produce an effect similar to an exogenous change in lottery ticket prices. This is because rollovers generate a change in the expected value of tickets—-defined as the price of the ticket minus the expected winnings. 
Rollovers thus provide the variation of price necessary to estimate the price elasticity of demand for lottery tickets in many contexts [Farrell and Walker 1999]. For example, United Kingdom residents can play the National Lottery, a game in which individuals must match 6 numbers drawn from 49 numbers without replacement in order to win a jackpot of millions of pounds. In one analysis, Farrell et al. [1999] use aggregate sales data from the United Kingdom's weekly drawings over the period November 1994 to February 1997, and report elasticities ranging from -1.04 to -1.55 , depending on the length of time considered. In a later study on the same lottery, Farrell et al. [2000] find the price elasticities over a slightly different time period, from November 1994 to February 1996, to be between -.80 to -1.06. Forrest et al. [2000] also study the same lottery from November 1994 to October 1997, using both rollovers and superdraws - episodic infusions of funds into the lottery to mark special occasions- to induce price variation and find the long-run price elasticity to be -1.03 . Finally, studies focusing on other parimutuel lotteries with rollovers such as in Canada and Israel have estimated price elasticities ranging from -.65 to -.67 [Beenstock and Haitovsky 2001; Yu 2008]. ${ }^{1}$

Because rollovers induce changes in the effective price of a lottery ticket and because rollovers are unique to lotto-type games, there has been relatively little research estimating price elasticities for daily lottery games. This study therefore introduces an innovative way to estimate the price elasticities of demand for daily New Jersey Pick 3 and Pick 4 "numbers" games using daily price variation created by so-called "bonus ball" promotions. At times, these games run bonus ball promotions for evening drawings - the Green Ball Double Draw for Pick 3 and the Red Ball Double Up for Pick 4-that result in players reaping larger than normal winnings. More specifically, the Pick 3 Green Ball Double Draw promotion pays prizes to two sets of winning numbers when a Green Ball is drawn from a secondary drawing hopper containing up to 
five or six white balls. The Pick 4 Red Ball Double Up promotion doubles prize payments for each winning ticket when a Red Ball is drawn from a secondary drawing hopper that holds up to six white balls. In effect, these promotions lower the price of a lottery ticket for an evening daily numbers game by increasing prize payments during the promotion period. Other states, including Ohio, Tennessee, Illinois, and Pennsylvania, have similar "bonus ball” promotions, but have different odds and prize packages. ${ }^{2}$

In this paper, we estimate price and cross-price elasticities for the Pick 3 and Pick 4 daily numbers games to determine whether the Pick 3 Green Ball and Pick 4 Red Ball promotions increase New Jersey Lottery profits using daily lottery data from July 1, 2004 until April 15, 2009. In addition, because instant games also have daily sales, we are able to estimate the crossprice elasticities for instant games with respect to Pick 3 and Pick 4 prices. ${ }^{3}$ We also estimate lag effects of the Pick 3 and Pick 4 promotions. We find that both the Green Ball and Red Ball promotions lose money on the promoted lottery product during its "bonus ball" promotion because its demand is price inelastic. However, the Green Ball promotion stimulates enough greater sales of Pick 3, Pick 4, and instant games in the 75 days after the promotion ends to increase net New Jersey Lottery profits by about $\$ 14.5$ million. In contrast, the Red Ball promotion reduces net lottery profits by about $\$ 2.6$ million because higher sales after the evening Pick 4 promotion do not offset the losses from greater prizes paid during the promotion, and the Red Ball promotion negatively affects the sales of instant games. ${ }^{4}$

\section{THE NEW JERSEY PICK 3 AND PICK 4 GAMES AND RELATED GREEN BALL AND RED BALL PROMOTIONS}

The New Jersey Lottery sells several lottery products having a wide variety of characteristics. During fiscal year 2007, sales of instant games (“scratch tickets") comprised 
$50.8 \%$ of $\$ 2.4$ billion in total lottery sales, followed by Pick 3 games (19.1\%), Pick 4 games (10.9\%), Mega Millions (10.1\%), Jersey Cash 5 (5.1\%), Pick 6 Lotto (3.7\%), and raffle sales $(0.4 \%) .^{5}$ Pick 3 and Pick 4 daily numbers games offer smaller prizes, more frequent drawings, and higher odds of winning each game's top prize than the Pick 6 and Mega Millions large jackpot lotto games, each of which have twice-weekly drawings. Jersey 5 , with daily sales and prizes, has a jackpot that rolls over like lotto, but has somewhat smaller prizes. Interestingly, Pick 3 and Pick 4 games are similar to the illegal numbers games that operated before the creation of the New Jersey Lottery in 1970, and have an enduring popularity, making up close to $30 \%$ of sales of New Jersey Lottery games.

In the regular Pick 3 New Jersey Lottery game, players place bets on the outcome of three independent drawings of numbers ranging from 0 to 9. In a Pick 3 "straight" bet, players have a 1 in 1,000 chance of matching all three winning numbers in exact order. Players can also place box bets--that their three numbers will be selected in any order--or can place a bet on whether just a pair of numbers will be drawn. The New Jersey Lottery runs two drawings per day of the Pick 3 game, a midday drawing at 12:57 p.m. and an evening drawing at 7:56 p.m.

The Pick 4 game operates in the same way as the Pick 3 game, except with four independent drawings of numbers ranging in value from 0 to 9 instead of three. A straight Pick 4 bet has a 1 in 10,000 chance of selecting all four numbers in order. There are also Pick 4 bets that can be placed to match the numbers drawn regardless of the order in which the numbers are selected.

In terms of possible winnings, in a typical Pick 3 and Pick 4 drawing, "fifty percent of the total amount of all bets for each game [is to] be placed in the game's prize pool to be shared by the winners in accordance with a parimutuel formula." ${ }^{6}$ In parimutuel games, the total amount of 
prize money is fixed and the exact prizes paid depend on the number of bets placed on the winning numbers. The total amount of prize money is then split among all winning tickets. Thus in New Jersey, bets on popular numbers, like 7-7-7 or the date of the drawing, have a much lower expected value than bets on less popular numbers because the odds of winning are the same for all numbers but the payouts are higher for numbers that are selected by fewer lottery players. $^{7}$ During non-promotion periods, the expected value of an average $\$ 1.00$ Pick 3 or Pick 4 New Jersey lottery ticket is $\$ 0.50$ and the cost of purchasing a dollar of expected Pick 3 or Pick 4 prize payment is $\$ 2.00$.

The redemption rules for lottery winners vary depending on the size of the prize won, affecting the convenience of additional wagering. Prizes under $\$ 599.50$ are validated and paid in cash by any of over 6,000 New Jersey Lottery retailers. All standard Pick 3 bet prizes, the vast majority of instant ticket prizes, and some Pick 4 prizes are under \$599.50. Prizes larger than this amount, such as the Pick 4 straight bet prize, may be validated at a lottery retailer, but the winner must wait approximately three weeks for a check to arrive in the mail from the New Jersey Lottery. The lottery reports these larger prizes to the Internal Revenue Service, and may also withhold state and federal income taxes depending on the size of the prize. ${ }^{8}$

Critical to the analysis here, the New Jersey Lottery operates special 28-day promotions called the Green Ball Double Draw and the Red Ball Double Up. At most, each of these promotions take place once per year according to New Jersey Lottery policy, and their implementation takes place independent of changes in lottery revenue. The Green Ball Double Draw promotion increases the expected value of an evening Pick 3 bet by drawing two sets of winning numbers instead of just one. This increase in expected value reduces the effective price of a bet. The Green Ball promotion only takes place during the evening drawing. It starts with 
either five or six white balls ${ }^{9}$ and one Green Ball in a secondary drawing hopper. If the Green Ball is drawn, then two sets of winning Pick 3 numbers are drawn. In contrast, when a white ball is drawn, that white ball is removed from the hopper before the next evening's Green Ball drawing. This promotional rule makes the expected value of the evening Pick 3 drawing vary randomly during the Green Ball promotion. Ultimately, if only the Green Ball is left, that evening's odds of winning are roughly doubled since two sets of winning numbers will be drawn. After a Green Ball is drawn, the promotional hopper is reset with the initial number of white balls and one Green Ball.

The Red Ball Double Up promotion increases the expected value of an evening Pick 4 bet by doubling the prize paid for each winning ticket during the promotion when a Red Ball is drawn, instead of paying prizes to a second set of winning numbers. Operationally, the Red Ball Double Up promotion starts with six white balls and one Red Ball in a hopper. ${ }^{10}$ If the Red Ball is selected during the evening Pick 4 drawing, then all winning prizes are doubled. If, on the other hand, a white ball is drawn, then that white ball is removed before the next evening's Red Ball drawing. When only a Red Ball remains in the promotional hopper, that evening's prize payments are guaranteed to be doubled since the Red Ball has to be drawn. After a Red Ball is drawn, that hopper is reset. These rules make the expected value of the evening Pick 4 lottery ticket vary randomly during the Red Ball Double Up promotion. The Red Ball promotion increases the expected value and reduces the effective price of an evening Pick 4 lottery ticket.

The Green Ball Double Draw promotion for Pick 3 and the Red Ball Double Up promotion for Pick 4 provide natural experiments that we exploit to estimate the demand for daily lottery games in New Jersey. ${ }^{11}$ As described above, it is usually difficult to estimate the demand for a product based on historical data on prices and the quantity or volume of sales 
because of the identification problem. Fortunately, the random changes in prices for Pick 3 and Pick 4 caused by the promotions identify the demand curve without the need to use more complex econometric methods such as instrumental variables estimation and two stage least squares techniques. ${ }^{12}$ When there are six white balls and one Green Ball in the hopper for the Green Ball Double Draw promotion, the expected value of a dollar lottery ticket is \$.5714. Of this amount, fifty cents is due to the expected value of the normal prize pool being $50 \%$ of the Pick 3 sales. The extra $\$ .0714$ is due to the one in seven chance of the Green Ball being drawn during this promotion and the New Jersey Lottery paying prize payments for two sets of winning Pick 3 numbers. The lottery provides the additional prize money when a Green Ball is drawn by reducing its take-out rate in the hopes of gaining additional sales. The cost of a dollar of expected Pick 3 prizes is $\$ 1.75$ when there are six white balls and one Green Ball during the promotion.

As the number of white balls falls, the odds of winning increase during the Green Ball Double Draw promotion and the price of a Pick 3 lottery ticket declines. The average cost of $\$ 1.00$ of expected prize winnings is $\$ 1.00$ when there is a $100 \%$ chance of drawing a Green Ball. Due to the parimutuel nature of the New Jersey Pick 3 game, when a Green Ball is guaranteed to be drawn, bets on unpopular numbers will have a positive expected return while bets on popular numbers will still have a negative expected return.

The variation in prices for the Pick 4 lottery similarly occurs during the Red Ball Double Up promotion, and so by extension, all of the above discussion on price changes applies to Pick 4 as well. The combination of the parimutuel prizes and the Pick 4 Double Up promotion creates the possibility that a limited number of bets on unpopular numbers may have a positive expected value. When only the Red Ball is left for an evening drawing, lottery players know that the 
prizes for winning Pick 4 bets will be doubled that evening because of the Pick 4 Double Up promotion. This means that a small bet on unpopular numbers under these circumstances will have a positive expected value. ${ }^{13}$

\section{SALES OF PICK 3 AND PICK 4 LOTTERY TICKETS DURING PROMOTIONAL AND NON-PROMOTIONAL PERIODS}

The data for the following analyses came from the New Jersey Lottery. This includes daily data from July 1, 2004 until April 15, 2009 on sales of Pick 3 and Pick 4 numbers games and winning prize payments, and on sales of instant games. ${ }^{14}$ The lottery did not hold drawings for Pick 3 and Pick 4 on Christmas Day and from July 3 to July 7, 2006 because of a New Jersey government shutdown. There are a total of 1,740 days of Pick 3 and Pick 4 lottery sales and drawings in the sample. Because no instant games sales were recorded by the lottery on the day before the government shutdown, we have only 1,739 days of sales data for instant games.

\section{Green Ball Double Draw Promotion}

Table 1 shows average sales for the evening and midday Pick 3 and Pick 4 New Jersey numbers games in relation to the Green Ball promotion. The averages are displayed for the entire sample, during and outside of the Green Ball promotion, and by the number of white balls in the secondary drawing. When a previous secondary Green Ball evening drawing results in a white ball being drawn, that white ball is removed from the secondary drawing and the odds of a Green Ball being drawn increase for the next drawing as shown in the second column. Columns 3-4 illustrate the expected value of a dollar bet and the cost of a dollar of expected winnings in relation to the promotion.

[Table 1 about here]

As column 5 illustrates, average evening Pick 3 sales increase from $\$ 785,896$ outside of a Green Ball promotion to $\$ 877,136$ during the Green Ball promotion. As expected, average 
evening Pick 3 sales increase during the promotion as the number of white balls in the Green Ball secondary drawing decreases. This effect is monotonic, except when comparing drawings with six white balls to drawings with five white balls, where average sales drop when the odds improve. In order to illustrate why this might be the case, the last two rows of the table break the days with six white balls into two categories: days after a Green Ball is drawn and two sets of prizes are awarded, and the first day of a promotion that does not follow the drawing of a Green Ball. Sales are $\$ 56,996$ higher the day after a Green Ball is drawn, when there are six white balls in the drawing. Because consumers can cash in all Pick 3 winning tickets at their lottery retailers, this might suggest that some of the extra prize payments from the Green Ball promotion are used to purchase additional Pick 3 lottery tickets for the following evening.

Columns 6-8 show that average sales for the evening Pick 4, midday Pick 3, and midday Pick 4 lottery drawings are all higher during the Green Ball promotion. This is notable because the Green Ball promotion only applies to the evening Pick 3 drawing. That is, a reduction in midday Pick 3 and all Pick 4 sales might have been anticipated because the expected price of the evening Pick 3 game falls during the Green Ball promotion. A bettor would only have to wait an additional seven hours for the realization of the outcome of a Pick 3 bet in order to have a chance of benefiting from two sets of winning Pick 3 numbers being drawn during the Green Ball promotion.

\section{Red Ball Double Up Promotion}

Table 2 shows average sales for the evening and midday Pick 3 and Pick 4 New Jersey lottery drawings for the entire sample, during and outside of the Red Ball promotion, and by the number of white balls in the secondary drawing. When a previous secondary Red Ball evening drawing results in a white ball being drawn, that white ball is removed from the secondary 
drawing and the odds of a Red Ball being drawn increase for the next drawing as shown in column 2. Columns 3-4 demonstrate the expected value of a dollar bet and the cost of a dollar of expected winnings during the Red Ball promotion, which are exactly the same as during the Green Ball promotion.

[Table 2 about here]

As column 6 demonstrates, average evening Pick 4 sales increase from $\$ 481,193$ outside of a Red Ball promotion to $\$ 534,231$ during the Red Ball promotion. Average evening Pick 4 sales generally rise during the promotion (but not completely monotonically) as the number of white balls in the Red Ball secondary drawing decreases. Similar to the Green Ball promotion, the last two rows in the table break the days with six white balls into two categories: days after a Red Ball is drawn and prizes are doubled, and the first day of a promotion that does not follow the drawing of a Red Ball. Sales are $\$ 9,401$ higher the day after a Red Ball is drawn when there are six white balls in the drawing. Although not definitive, this suggests that part of the double prize payments from the Red Ball promotion may be used to purchase additional Pick 4 lottery tickets for the following evening.

Columns 5 and 7 show that the average sales for evening Pick 3 and midday Pick 3 lottery drawings fall slightly during the Red Ball promotion. Interestingly, sales for midday Pick 4 lottery drawings increase $\$ 10,095$ during the Red Ball promotion as shown in column 8 even though the promotion only applies to the evening Pick 4 drawing. This might suggest that some bettors do not understand that the promotions only apply to the evening lottery drawings, or that they may spend additional Red Ball prize payments for a variety of drawings.

Overall, the sales data are consistent with the idea that there are costs for consumers to acquire information about the rules of the Green Ball and Red Ball promotions. In fact, lottery 
consumers may not invest the time to calculate the exact odds and expected value of a ticket as a function of the number of white balls in the promotional drawing hopper, which leads to some of the unexpected findings here. However, they do seem to have a general idea that the Pick 3 or Pick 4 evening drawing is a better deal when there are fewer white balls left in the promotional drawing hopper for each respective game. Consistent with this, our results indicate that on average, New Jersey Lottery consumers generally respond to lower prices/higher expected values by increasing their purchases when the odds improve during the Green Ball and Red Ball promotions.

\section{MODEL SPECIFICATION}

We then turn to building four regression models for Pick 3 and Pick 4 games, with the dependent variables being the logarithms of evening Pick 3 sales, evening Pick 4 sales, midday Pick 3 sales, and midday Pick 4 sales. We used a logarithmic specification for the price variables so that the coefficients can be interpreted as own- and cross-price elasticities. Overall, we considered two sets of independent variables in the models. The first set directly relates to the promotions themselves; these variables are used to estimate the state lottery profits that they generate. The second set of variables includes a variety of other factors that impact ticket sales.

Turning to this first set of variables, we included the logarithms of the evening Pick 3 and evening Pick 4 prices to estimate the own-price elasticity of demand for these games. We used the expected cost of purchasing a dollar of winnings as our price measure. We also incorporated the influence of the price of competing lottery products, which previous work has demonstrated to have mixed results on sales. Lin and Lai [2006], for example, employed data from all of the 104 draws in 2004 for the Big Lotto (a 6/49 game) and the regular Lotto (a 6/42 game) in Taiwan and found no significant substitutive or complementary relationships between single draws of 
these games. Other research has suggested that governments need to be aware that some games might be at least partial substitutes for one another [Forrest et al. 2004; Thalheimer 2008; Thalheimer and Ali 2003]. Yet other research has produced evidence that some lottery games are complements for one another [Combs and Spry 2012; Grote and Matheson 2006]. Summarizing their 2006 results, Grote and Matheson [2011, p. 9] conclude that "transactions costs and the ability to buy multiple types of game tickets at the same time are responsible for the complementarities exhibited by lottery buyers." The inclusion of the logarithm of the evening Pick 3 price and evening Pick 4 price thus also enables us to test whether each of these games is a complement to or substitute for other lottery games.

We model the error structure with an AR(1) specification due to serial correlation, possibly caused by daily lottery ticket purchasing habits. Large lottery sales volume on one day may lead to higher sales volume the next day, as winners of prizes less than $\$ 599.50$ can cash in their winning tickets at lottery retailers, where they can conveniently buy additional lottery tickets. Since the variation in the price of the daily games occurs at high frequency (daily) during the 28 days of a Green Ball or Red Ball promotion and not over long periods of time, we view our results as providing high frequency or short-run price elasticities. ${ }^{15}$

Other research has explored the impact of spillover effects on sales. This research tests whether the playing excitement produced in one time period affects future sales; this excitement could be prompted by lottery promotions or the prevalence of winning tickets. Grote and Matheson [2007] find evidence that lotto ticket sales are unexpectedly high following a large jackpot, and that this is the result of players exchanging prize winnings for new tickets. Similarly, Guryan and Kearney [2009] report increased lotto sales in a particular zip code following a jackpot won in that zip code. For New Jersey, we wish to test whether a daily 
game's promotion has a positive impact on sales after the promotion ends. Therefore, in all four models, we incorporated a specification to allow for a general boost in sales after the promotion that is largest immediately after a promotion and declines over time. After examining the raw data, we chose a period of 75 days as this post-promotion "lag" period. ${ }^{16}$ Next, we included a dummy variable equal to one for each of the 75 days after each Green Ball promotion. Finally, to measure the decay from the boost captured by that dummy variable, we included an additional variable equal to 75 minus the number of the days since a Green Ball promotion ended, for each of the 75 days after the promotion concluded. Each of the regressions includes two similar variables for the Red Ball promotions.

Beyond examining these promotion-related variables, our second set of independent variables includes other factors that impact sales. One of the main factors that might influence purchasing decisions relates to the timing of paychecks and other benefits that players might receive, or income infusions. If the majority of individuals receive payments of this type at the beginning of each month or on a Friday, they might have a feeling of optimism and be more likely to spend money on lottery tickets. In addition, they might be less likely to spend money at the end of the month. The only previous work related to this lottery participation topic was conducted by Akay et al. [2008]. Their analysis focused on bi-weekly games with fewer observations using monthly income infusion variables among other controls, and daily games using GARCH models—which only included days of the week as income-related variables and no other controls. They find no evidence of monthly income effects but some evidence of increased spending on Fridays in their GARCH models. In this analysis, we tested the effects of both monthly and daily income infusions. In doing so, we included dummy variables for the first and last five days of each month. In New Jersey, several counties prohibit malls and certain 
other retailers from opening on Sundays. These laws could reduce sales on Sundays similar to blue laws for liquor sales [Stehr 2007]. Therefore, we also included dummy variables for each day of the week, with Sunday as the omitted category.

In addition to the income infusions, we included several other determinants of lottery sales. We used the logarithm of the Mega Millions jackpot to test whether larger jackpots in this game change the purchasing behavior of players in each Pick 3 and Pick 4 game. The parimutuel nature of the Pick 3 and Pick 4 prize payments also offers an opportunity to test the effects of the size of prize payments on sales for the next day's drawing. When a popular set of numbers is drawn, the size of the parimutuel prizes is smaller, but more lottery players receive winnings. When an unpopular number is drawn, fewer prizes are awarded, but each prize is larger. We included the size of the prize payments for the previous two Pick 3 drawings in each Pick 3 midday and evening model. Similarly, we incorporated the size of the prize payments into the previous two Pick 4 drawings for each Pick 4 midday and evening model.

In addition, previous studies have found mixed effects of each state's macro-economy on lottery sales. For example, Mikesell [1994], using pooled data for states with lotteries, finds that lottery sales increase at the state level with increases in the state's unemployment rate. In contrast, Blalock et al. [2007] find that higher unemployment rates lead to lower lottery sales. We therefore included the seasonally adjusted New Jersey unemployment rate, obtained from the New Jersey Department of Labor. ${ }^{17}$

The existing literature on lottery demand has not estimated the effects of changes in gasoline prices on lottery sales, but weekly grocery store scanner data show that higher gasoline prices affect grocery purchases. Gicheva et al. [2010] demonstrate that consumers respond to higher gasoline prices by substituting towards sale items. We used daily average New Jersey 
gasoline price data from gasbuddy.com to estimate the short-run cross-price elasticity of lottery tickets with respect to gasoline prices.

As another factor influencing sales, a governmental shutdown in New Jersey, which temporarily prevented individuals from buying lottery tickets, enables us to estimate how lottery consumers respond to this short-term break in ticket availability. Previous research has explored this issue of consumer planning only when another gambling product becomes relatively more attractive in the short-term, not when products are partially or completely inaccessible to the public [Forrest et al. 2010]. We hypothesized that consumers have a "lottery budget" and that consumers spend this budget down early in anticipation of a governmental shutdown. We included a dummy variable for July 2, 2006, the day before the New Jersey government closed from July 3 to July 7, 2006 (due to a budget dispute between the governor and the legislature).

Holiday periods may also account for some disruptions in normal lottery ticket purchasing patterns. Although lottery tickets are sold and lottery drawings take place on twelve of the thirteen major New Jersey holidays, ${ }^{18}$ we hypothesized that consumers would engage in different buying behavior due to alterations in their typical work week. We therefore included dummy variables for the day of, the day before, and the day after each state holiday with lottery sales.

Finally, we explored the influence of weather on sales. Previous research has examined the impact of both temperature and precipitation on the sale of various goods, with mixed results [Miron 1986; Starr-McCluer 2000]. We used data on daily precipitation in inches at Newark Airport obtained from the Office of the New Jersey State Climatologist. ${ }^{19}$ 
Overall, we estimate the following series of regression equations, one for each of the four Pick 3 and Pick 4 lottery games, using the full sample of 1,740 daily observations. We included a time trend to control for long-run growth or decline in sales of any particular lottery game:

Models 1 through 4 (Pick 3 and Pick 4 midday and evening drawings): $\ln \left(\right.$ Sales $\left._{t}\right)=\beta_{0}+\beta_{1} \ln \left(\right.$ Own Price $\left._{t}\right)+\beta_{2} \ln \left(\right.$ Other Game Price $\left._{t}\right)+\beta_{3}{ }^{\prime}$ Spillover Effects $_{t}+\beta_{4}{ }^{\prime}$ Income Infusions $_{\mathrm{t}}+\beta_{5} \ln \left(\right.$ Mega Millions Jackpot $\left._{\mathrm{t}}\right)+\beta_{6}{ }^{\prime}$ Parimutuel Prize Payments $_{\mathrm{t}}+\beta_{7}$ Unemployment Rate $_{\mathrm{t}}+\beta_{8} \ln (\text { Gas Price })_{\mathrm{t}}+\beta_{9}$ Lottery Availability $_{\mathrm{t}}+\beta_{10}$ Precipitation $_{\mathrm{t}}+\beta_{11}$ trend $+\beta_{12}$ Days $_{\mathrm{t}}+$ $\rho \cdot \ln \left(\right.$ Sales $\left._{\mathrm{t}-1}\right)+\varepsilon_{\mathrm{t}}$

We also estimate two additional regression equations, one for instant games and the other for the sum of the four Pick 3/Pick 4 games and instant games. These models allow us to examine the extent to which the Red or Green Ball promotions affect sales of other lottery games in New Jersey. We used the same specification as the Pick 3 and Pick 4 regression models, with three exceptions. First, instant games have no variation in price so we omitted the own-price variable. Also, we omitted the Pick 3/Pick 4 parimutuel prize variables since they did not even have a statistically significant effect on Pick 3/Pick 4 sales. Finally, because the New Jersey Lottery did not record sales of instant games on the day before the state government shutdown (which we attribute to lottery accounting methods), we omitted the variable for the day before the government shutdown, and used only 1,739 daily observations:

Models 5 and 6 (Instant Games and Pick $3+$ Pick 4 + Instant Games): $\ln \left(\right.$ Sales $\left._{\mathrm{t}}\right)=\beta_{0}+\beta_{1} \ln \left(\right.$ Other Game Price $\left._{\mathrm{t}}\right)+\beta_{2}{ }^{\prime}$ Spillover Effects $\mathrm{t}_{\mathrm{t}}+\beta_{3}{ }^{\prime}$ Income Infusions $_{\mathrm{t}}+\beta_{4}$ $\ln \left(\right.$ Mega Millions Jackpot $\left.{ }_{\mathrm{t}}\right)+\beta_{5}$ Unemployment Rate $_{\mathrm{t}}+\beta_{6} \ln (\text { Gas Price })_{\mathrm{t}}+\beta_{7}$ Lottery Availability $_{t}+\beta_{8}$ Precipitation $_{t}+\beta_{9}$ trend $+\beta_{10}$ Days $_{t}+\rho \cdot \ln \left(\right.$ Sales $\left._{t-1}\right)+\varepsilon_{t}$

Taken together, Models 5 and 6 allow us to estimate determinants for approximately $80 \%$ of the sales of the New Jersey Lottery. We cannot properly estimate the effects of the promotion on the remaining $20 \%$ of sales mainly because of the unavailability of high-frequency data. ${ }^{20}$ Even so, our unreported, interpolated demand estimates for the Mega Millions and Pick 6 Lotto indicated no statistically significant effects of the Red and Green Ball promotions on sales, and 
the estimated positive effect of the Green Ball promotion on Jersey 5, which accounts for just around $5 \%$ of lottery sales, is only statistically significant at the $90 \%$ confidence level.

\section{RESULTS}

Table 3 shows descriptive statistics for the abbreviated sample of 1,739 days with sales for all Pick 3/Pick 4 drawings and instant games. Before moving to the regression analyses, we test for the presence of a unit root in each of our time series: midday Pick 3 sales, evening Pick 3 sales, midday Pick 4 sales, evening Pick 4 sales, instant games sales, and the sum of all the above games. This is to ensure that our dependent variables are trend-stationary and our regression results are not spurious.

[Table 3 about here]

We use the augmented Dickey-Fuller test ${ }^{21}$ for the presence of a unit root in the level of these six time series. The null hypothesis is that the level of the series has a unit root and the alternative hypothesis is that there is not a unit root. We are able to strongly reject that there is a unit root in the dependent variables. This allows us to proceed to estimate the demand for New Jersey Lottery tickets using regression analyses.

The elasticity and regression results for Pick 3 and Pick 4 games are reported in Table 4. While the coefficients on the continuous logarithmically transformed independent variables are easily interpreted from the tables as elasticities, the coefficients for the dummy variables do not directly have a meaningful explanation. Therefore, Table 5 reports the estimated percentage changes in sales attributable to the non-holiday dummy variables that are statistically significant at the $95 \%$ confidence level, while Table 6 reports the percentage changes in sales attributable to each of the statistically significant holiday dummy variables at the same confidence level.

[Tables 4, 5, and 6 about here] 
Examining the effect of the first set of independent variables directly related to the promotions, the demand for evening Pick 3 games (Model 1) and for evening Pick 4 games (Model 2) are both price-inelastic, with own-price elasticities of demand of -.47 and -.52, respectively. ${ }^{22}$ Therefore, the own-price effects reduce each evening game's revenue during its promotion period because the increase in sales volume of the promoted game does not offset its reduced price during the promotion period.

The promotions for the evening drawings positively affect sales of their daytime counterparts. The Green Ball promotion increases midday Pick 3 sales, with a cross-price elasticity of -.18 (the estimated coefficient of log of the evening Pick 3 price in Model 3), and the Red Ball promotion increases midday Pick 4 sales, with a cross-price elasticity of -.09 (the estimated coefficient of log of the evening Pick 4 price in Model 4). These cross-price elasticities are interesting because they show that midday lottery sales of the promoted daily lottery game increase during the promotion, instead of decreasing from lottery players switching to the promoted evening drawing that offers better odds. If lottery players would wait an additional seven hours for the resolution of their bet, they could receive much better odds. Yet, the data show that the midday and evening drawings within the Pick 3 and Pick 4 games are clearly complements for one another. There are several possible explanations for this behavior. It could mean, for example, that New Jersey Pick 3 and Pick 4 lottery consumers may buy midday tickets because they do not understand that the promotions only apply to evening draws; they get caught up in the general publicity of the promotions and buy more midday tickets overall; they are impatient in terms of their betting behavior; or they purchase more midday tickets when redeeming additional winning tickets from the evening drawings. 
The Green Ball promotion for the evening Pick 3 drawings has a complementary effect of increasing the sale of both Pick 4 games. More specifically, as Model 2 demonstrates, the crossprice elasticity of demand for the evening Pick 4 game with respect to the price of the evening Pick 3 game is -.13 (significant at the $99 \%$ confidence level), and Model 4 shows that the crossprice elasticity of demand for the midday Pick 4 game with respect to the price of the evening Pick 3 game is -.06 (but is only significant at the $90 \%$ confidence level).

In contrast, the Red Ball promotion for Pick 4 has a modest negative effect on midday Pick 3 sales as Model 3 indicates, with the cross-price elasticity of these sales with respect to the evening Pick 4 price estimated to be .08 . Sales of evening Pick 3 lottery tickets are not affected by the Red Ball promotion's reduction in the price of evening Pick 4 tickets. ${ }^{23}$

Sales increase across all four daily numbers games the day after a Green Ball is drawn. As shown in Table 5, the point estimates of the percentage change in these sales range from between 3.3\% for evening Pick 4 to 5.6\% for midday Pick 3. This could suggest that lottery players may use the additional prize payments from the Green Ball promotion to buy a variety of additional lottery products for the following day. In contrast to these positive effects after a Green Ball is drawn, sales of Pick 3 tickets decline for both midday and evening drawings the day after a Red Ball is drawn, and Pick 4 sales are unaffected.

The difference in redemption rules for larger prizes may help to explain the differences in spillover effects and complementary relationships of the Pick 3 promotion as compared to the Pick 4 promotion. The observed positive spillover and cross-game effects from the Pick 3 Green Ball promotion are consistent with a transactions cost argument because all Pick 3 prizes are under the $\$ 599.50$ threshold, allowing winners to redeem all Pick 3 prizes at a lottery retailer. Thus, additional tickets for any type of game may be purchased on the spot when redeeming 
additional Pick 3 winnings during the promotion. However, the prizes for several Pick 4 bets, including the straight bet, exceed the threshold for redemption at a lottery retailer. Winners of these larger Pick 4 prizes must wait three weeks for their checks to arrive in the mail, without immediate access to their additional Pick 4 winnings, and are not present at a lottery retailer when they eventually receive their checks. In addition, there are many more winning tickets for Pick 3 than Pick 4 because Pick 4 offers longer odds than Pick 3. As described previously, all of these differences are accentuated during the promotions.

Over the longer term, the Green Ball drawing stimulates higher sales for all Pick 3 drawings as well as Pick 4 drawings for 75 days after the promotion's end. Taken together, the Green Ball 75-day lag variables demonstrate a bump in sales of all Pick 3 and Pick 4 games that is highest at the beginning of the 75-day period, and generally declines over the 75-day period. However, the Red Ball promotion increases only evening Pick 4 sales and midday Pick 4 sales (with a subsequent decline) during the 75-day period after the promotion's end.

Turning to the second set of independent variables in the regression results, there is evidence that income infusions influence lottery sales. First, as Table 5 demonstrates, sales of each of the four numbers games increase by an estimated $4.0 \%$ to $4.6 \%$ during the first five days of the month. There is no statistically significant effect of the last five days of the month on numbers games sales. We also find strong day-of-week effects, with Friday as the most popular day of the week for playing numbers games, and Sunday, the omitted day of the week, as the least popular. For example, evening Pick 3 sales on Fridays are 37\% higher than on Sundays. Overall, the day-of-week effects are also larger for the evening numbers drawings than for the midday drawings. 
Regarding prize sizes, the size of the Mega Millions jackpot has a small positive effect on both evening Pick 3 and evening Pick 4 sales, but on neither of the midday games. However, the sizes of recent Pick 3 and Pick 4 parimutuel prizes have no statistically significant effect on the sales of any numbers game at the $95 \%$ confidence level.

The regression results show that higher unemployment has a small negative effect on daily lottery sales. A one percentage point increase in the New Jersey unemployment rate reduces evening Pick 3 sales by $1.0 \%$, midday Pick 3 sales by 1.8\%, and midday Pick 4 sales by $0.8 \%$. The unemployment rate does not have a statistically significant effect on evening Pick 4 sales.

We find that higher gasoline prices have a small negative effect on lottery sales. The cross-price elasticity of demand for lottery sales with respect to gasoline prices is about -.04 for evening Pick 3, -.09 for evening Pick 4, and -.05 for midday Pick 4. The cross-price elasticity of demand for midday Pick 3 sales with respect to gasoline prices is -..02, but is less statistically significant.

The regression results presented here also suggest that consumers may have a lottery budget and therefore plan for several types of disruptions in lottery ticket sales. There are large increases in sales of both the Pick 3 and Pick 4 games immediately prior to the New Jersey government shutdown that prevented the lottery from operating for five days in July 2006. As Table 5 demonstrates, evening Pick 3 sales increased 43.2\%, while evening Pick 4 sales expanded $42.6 \%$ on the day before the government shutdown. Midday Pick 3 sales also rose 29.5\%, while midday Pick 4 sales increased $29.0 \%$ the day before the government shutdown. It appears lottery players anticipated that a political stalemate could shut down the lottery and bought extra tickets while the lottery was still operating. 
Interestingly, inclement weather in the state has a small, negative effect on the sales of New Jersey lottery games. Sales for each of the Pick 3 and Pick 4 drawings decrease by approximately $2 \%$ for each additional inch of precipitation. Consumers therefore appear to be reluctant to engage in gambling opportunities when there are some weather-related inconveniences in doing so. Perhaps rain or snow increases transactions costs leading to fewer trips to lottery retailers.

Examining holiday effects, Table 6 shows how periods surrounding many New Jersey state holidays affect numbers games sales. Perhaps the most interesting of these holiday periods is the Thanksgiving Day weekend. ${ }^{24}$ The day before Thanksgiving is the busiest travel day of the year in the United States, so lottery sales decline on that day by between about $9 \%$ and $11 \%$ for all Pick 3 and Pick 4 games. Sales drop by close to $30 \%$ on Thanksgiving Day for evening games, and by a lesser amount for midday games. The day after Thanksgiving is the most popular shopping day of the year in the U.S., and it appears to be a popular day for lottery purchases as well. All numbers games experience an increase in sales ranging from about $10 \%$ to $15 \%$. A quick glance at Table 6 shows the wide variation in the impact of other holiday periods on Pick 3 and Pick 4 sales.

Finally, the time trend is slightly negative for evening Pick 3 sales. The time trend is slightly positive for midday Pick 3 and Pick 4 sales but not statistically significant for evening Pick 4 sales. Therefore, while there has been positive long-term growth in one Pick 4 game and the midday Pick 3 drawing, evening Pick 3 sales show a slight long-term decline.

Turning to Models 5 and 6, the regression results for instant games and the sum of Pick 3, Pick 4, and instant games are reported in Table 7. Tables 8 and 9 report the estimated percentage 
changes in sales of these time series that can be attributed to dummy variables at the $95 \%$ confidence level.

[Tables 7, 8, and 9 about here]

We find that sales of instant games respond positively to Pick 3 promotions but negatively to Pick 4 promotions. More specifically, Model 5 in Table 7 shows that the crossprice elasticity of the sales of instant games is -.18 with respect to the price of the evening Pick 3 game, yet .11 with respect to the price of evening Pick 4 game. This pattern repeats itself with a lagged effect: as Table 8 shows, instant games sales are about $2.4 \%$ higher the day after a Green Ball is drawn, but $2.9 \%$ lower the day after a Red Ball is drawn. These higher sales after a Green Ball is drawn would be consistent with lottery customers making additional purchases of instant tickets when they cash in their additional winning Pick 3 tickets at lottery retailers.

In addition, the Green Ball promotion has a positive long term impact on instant games, with a bump up of instant games sales and subsequent decline during the 75-day period after the Green Ball promotion. However, instant games sales are reduced during the 75-day period after the Red Ball promotion.

Although our main interest in instant games pertains to the effects of the Pick 3 and Pick 4 promotions, Table 7 shows that many of the demand variables unrelated to the promotions also have a statistically significant effect on the sales of instant games. Like sales of numbers games, sales of instant games are higher the first five days of the month, and higher Monday through Saturday as compared to Sunday. A one percentage point increase in the unemployment rate decreases instant games sales by $4 \%$, which is much larger than the effect of unemployment on the numbers games. The amount of precipitation negatively affects instant sales; in addition, the demand for instant tickets has a cross-price elasticity of -.1 with respect to the price of gasoline. 
Many of the state holidays, including Thanksgiving, also affect sales of instant games. However, the Mega Millions jackpot does not have a statistically significant effect on the sales of instant games.

The demand estimates for Model 6, the sum of numbers games and instant games sales, are quite similar to those for instant games. This is not surprising because instant games dominate the New Jersey Lottery in terms of sales. The Pick 3 promotion positively affects the sum of sales of the numbers and instant games during the promotion period. However, it should be noted that the Pick 4 promotion has no effect on the sum of sales of the numbers and instant games overall during the promotion period. This latter result may be due to Pick 4 sales being positively affected by the Red Ball promotion while Pick 3 and instant games sales are negatively affected by the Red Ball promotion.

The total effect of the Green Ball Pick 3 promotion on New Jersey Lottery profits is the combined effect of the Green Ball promotion on profits from the evening Pick 3 game and the other daily lottery drawings during the promotion, and on the profits from the short-term increase in lottery sales after the promotion. ${ }^{25}$ The Green Ball promotion, which lasts 28 days, reduces the expected price of an evening Pick 3 ticket by $18 \%$ on average. Applying the regression results to average sales, the Green Ball promotion reduces daily profits from the evening Pick 3 game by approximately $\$ 57,000$ per day during the promotion period. The percentage reduction in the price of playing the evening Pick 3 lottery is greater than the increase in sales volume gain because of the inelastic own-price elasticity of demand.

Over the course of 28 days of the Green Ball promotion, the profits from midday Pick 3, midday Pick 4, and evening Pick 4 ticket sales increase by approximately $\$ 20,000$ per day in total because of the increased sales of these complementary numbers games. Profits from instant 
tickets increase by around $\$ 67,000$ per day during the Green Ball promotion. The combined effects of lower evening Pick 3 profits and increased sales of complementary products increases lottery profits by $\$ 30,000$ per day, or $\$ 840,000$ during the 28 days of the Green Ball promotion. In addition, the strong lagged effect of the Green Ball promotion on Pick 3, Pick 4, and instant sales over the 75 days after the end of a Green Ball promotion increases New Jersey Lottery profits by $\$ 13.64$ million. Therefore, the net effect of the typical Green Ball promotion over this longer time period is to increase profits by about $\$ 14.48$ million.

Because the evening Pick 4 game is price-inelastic, the 28-day Red Ball promotion reduces daily profits from the evening Pick 4 game by approximately $\$ 41,000$ per day during the promotion period. In addition, since the evening Pick 4 game is a weak complement with the midday Pick 4 game but a weak substitute for the midday Pick 3 game, the net effect of these changes in midday sales during the Red Ball promotion is an additional loss of $\$ 8,000$ in daily profits. Moreover, since the evening Pick 4 game is a substitute for instant games and instant games are the best-selling New Jersey lottery product, the reduction in instant sales reduces daily profits by $\$ 80,000$ during the Red Ball promotion. The combined effects of lower evening Pick 4 profits and reduced sales of substitute products reduces lottery profits by $\$ 129,000$ per day, or \$3.61 million during the 28 days of the Red Ball promotion.

In contrast to the Green Ball promotion, there are weaker lagged effects of the Red Ball promotion, because only evening and midday Pick 4 sales increase, as compared to their baseline, after the Red Ball promotion ends. Over the 75 days after the end of a Red Ball promotion, the New Jersey Lottery thus only makes an additional \$1.05 million in profits from the increase in evening and midday Pick 4 sales. Therefore, the net effect of the typical Red Ball 
promotion, even taking into account higher lagged sales, is a reduction in lottery profits of about \$2.56 million.

\section{CONCLUSIONS}

Estimating demand elasticities for lottery games has challenged researchers because the prices charged to the consumer for purchasing tickets usually do not change over time. To overcome this identification challenge, we estimate price elasticities for daily numbers games by exploiting the random price changes caused by two New Jersey Lottery initiatives: the Green Ball Double Draw and the Red Ball Double Up promotions. Overall, we find that the own-price elasticity of demand for the evening Pick 3 game is -.47 , while the own-price elasticity of demand for the evening Pick 4 game is -.52. In addition, the cross-price elasticities of the four midday/evening Pick 3/Pick 4 numbers games and of instant games, with respect to the Pick 3 and Pick 4 prices, range from -.18 to .11 .

The Pick 3 Green Ball and Pick 4 Red Ball promotions attempt to increase New Jersey State Lottery profits by expanding volume at the expense of the profit margin. However, the percentage price reduction during the promotions is greater than the percentage increase in ticket sales during the promotions. Due to this estimated inelastic demand, the Green Ball and Red Ball promotions reduce profits for the New Jersey Lottery during the period of the promotions. However, the Green Ball promotion stimulates greater sales of other numbers games and instant games during the promotion period, and has a sustained positive effect on sales of all numbers and instant games in the 75 days after the promotion ends, thereby increasing lottery profits during this time period. In contrast, the Red Ball promotion has a negative effect on some games during the promotion, and has only a weakly positive net sustained effect after the promotion. 
On balance, the Green Ball promotion increases profits for the New Jersey Lottery, whereas the Red Ball promotion causes a reduction in profits.

Why might we see these differences between the effect of the Pick 3 promotion and the Pick 4 promotion? One explanation stems from the combined effect of the differences in odds, prizes, promotion rules, and redemption rules for Pick 3 vs. Pick 4. Only prizes under $\$ 599.50$ may be cashed in at a lottery retailer, at which point it is convenient for winners to purchase additional lottery tickets for any of the New Jersey Lottery games. Pick 4 winners are much less likely to cash in their tickets at a lottery retailer, due to the longer odds and higher prizes of the Pick 4 game; rather, winners of higher prizes must wait three weeks for their winnings checks by mail. During the Pick 3 promotion, the "double draw" doubles the odds of winning when a Green Ball is drawn, producing an even greater number of winners, all of whom will cash in their prizes at retailers because all prizes are under the threshold. In contrast, the Pick 4 "double up" doubles the prize winnings when a Red Ball is drawn, thereby making it less likely the prize will be under the threshold for retailer redemption. The results suggest that the New Jersey Lottery's evening Pick 3 Green Ball promotion should be continued because it increases lottery profits over the long run. In contrast, lottery officials should consider ending the evening Pick 4 Red Ball promotion because it reduces lottery profits over the same time period. 


\section{References}

Akay, Ozzy, Mark D. Griffiths, and Drew B. Winters. 2008. An Examination of Two Competing Hypotheses for the Demand for Lottery Tickets. The Journal of Gambling Business and Economics, 2(1): 77-102.

Beenstock, Michael, Ephraim Goldin, and Yoel Haitovsky. 2000. What Jackpot? The Optimal Lottery Tax. European Journal of Political Economy, 16(4): 655-671.

Beenstock, Michael, and Yoel Haitovsky. 2001. Lottomania and Other Anomalies in the Market for Lotto. Journal of Economic Psychology, 22(6): 721-744.

Blalock, Garrick, David R. Just, and Daniel H. Simon. 2007. Hitting the Jackpot or Hitting the Skids: Entertainment, Poverty, and the Demand for State Lotteries. American Journal of Economics and Sociology, 66(3): 545-570.

Combs, Kathryn L., and John a Spry. 2012. Who Plays the Numbers Games in the Middle of the Day? Applied Economics, 44(7): 889-897.

Cook, Philip J., and Charles T. Clotfelter. 1993. The Peculiar Scale Economies of Lotto. American Economic Review, 83(3): 634-643.

Cuddington, John T., and Leila Dagher. 2011. A Primer on Estimating Short and Long-Run Elasticities: http://inside.mines.edu/ jcudding/papers/Elasticities/Cuddington-DagherEstimating\%20SR\%20and\%20LR\%20Elasticities(12-19-2011).pdf

Deboer, Larry. 1986. Lottery Taxes May Be Too High. Journal of Policy Analysis and Management, 5(3): 594-596.

Farrell, Lisa, Roger Hartley, Gauthier Lanot, and Ian Walker. 2000. The Demand for Lotto: The Role of Conscious Selection. Journal of Economic and Business Statistics, 18(2): 228241.

Farrell, Lisa, Edgar Morgenroth, and Ian Walker. 1999. A Time Series Analysis of U.K. Lottery Sales: Long and Short Run Price Elasticities. Oxford Bulletin of Economics and Statistics, 61(4): 513-526.

Farrell, Lisa, and Ian Walker. 1999. The Welfare Effects of Lotto: Evidence from the U.K. Journal of Public Economics, 72(1): 99-120.

Forrest, David, O. David Gulley, and Robert Simmons. 2000. Elasticity of Demand for U.K. National Lottery Tickets. National Tax Journal, 53(4): 853-863.

Forrest, David, O. David Gulley, and Robert Simmons. 2004. Substitution between Games in the U.K. National Lottery. Applied Economics, 36(7): 645-651. 
Forrest, David, O. David Gulley, and Robert Simmons. 2010. The Relationship between Betting and Lottery Play. Economic Inquiry, 48(1): 26-38.

Gicheva, Dora, Justine Hastings, and Sofia Villas-Boas. 2010. Investigating Income Effects in Scanner Data: Do Gasoline Prices Affect Grocery Purchases? American Economic Review, 100(2): 480-484.

Grote, Kent R., and Victor A. Matheson. 2006. Dueling Jackpots: Are Competing Lotto Games Complements or Substitutes? Atlantic Economic Journal, 34(1): 85-100.

Grote, Kent R., and Victor A. Matheson. 2007. Examining the 'Halo Effect' in Lotto Games. Applied Economic Letters, 14(4-6): 307-310.

Grote, Kent R., and Victor A. Matheson. 2011. The Economics of Lotteries: A Survey of the Literature: College of the Holy Cross, Department of Economics, Paper \# 11-09.

Gulley, O. David, and Frank A. Jr. Scott. 1993. The Demand for Wagering on State-Operated Lotto Games. National Tax Journal, 45(1): 13-22.

Guryan, Jonathan, and Melissa S. Kearney. 2009. Is Lottery Gambling Addictive? American Economic Journal: Economic Policy, 2(3): 90-110.

Lin, Chin-Tsai, and Chien-Hua Lai. 2006. Substitute Effects between Lotto and Big Lotto in Taiwan. Applied Economic Letters, 13(10): 655-658.

Matheson, Victor, and Kent R. Grote 2008. U.S. Lotto Markets, in Handbook of Sports and Lottery Markets, edited by Donald B. Hausch and William T. Ziemba. New York: North Holland.

Mikesell, John L. 1994. State Lottery Sales and Economic Activity. National Tax Journal, 47(1): 165-171.

Miron, Jeffrey A. 1986. Seasonal Fluctuations and the Life Cycle-Permanent Income Model of Consumption. The Journal of Political Economy, 94(6): 1258-1279.

Starr-Mccluer, Martha. 2000. The Effects of Weather on Retail Sales. Washington, DC: Federal Reserve Board Discussion Paper No. 2000-08 (Jan.).

Stehr, Mark. 2007. The Effect of Sunday Sales Bans and Excise Taxes on Drinking and CrossBorder Shopping for Alcoholic Beverages. National Tax Journal, 6(1): 85-105.

Terrell, Dek. 1994. A Test of the Gambler's Fallacy: Evidence from Pari-Mutuel Games. Journal of Risk and Uncertainty, 8(3): 309-317.

Thalheimer, Richard. 2008. Government Restrictions and the Demand for Casino and Parimutuel Wagering. Applied Economics, 40(6): 773-791. 
Thalheimer, Richard, and Mukhtar M. Ali. 2003. The Demand for Casino Gambling. Applied Economics, 35(8): 907-918.

Vrooman, David H. 1976. An Economic Analysis of the New York State Lottery. National Tax Journal, 29(4): 482-489.

Yu, Kam. 2008. Measuring the Output and Prices of the Lottery Sector: An Application of Implicit Expected Utility Theory. NBER Working Papers, No. 14020. 
Table 1

The expected value and price of Pick 3 lottery tickets vary with the number of white balls during a Green Ball promotion

\begin{tabular}{|c|c|c|c|c|c|c|c|c|}
\hline $\begin{array}{l}\text { Number } \\
\text { of White } \\
\text { Balls }\end{array}$ & $\begin{array}{l}\text { Odds of a } \\
\text { Green } \\
\text { Ball }\end{array}$ & $\begin{array}{l}\text { Expected } \\
\text { Value of a } \\
\text { Dollar Bet }\end{array}$ & $\begin{array}{l}\text { Cost of a } \\
\text { Dollar of } \\
\text { Expected } \\
\text { Winnings }\end{array}$ & $\begin{array}{l}\text { Average } \\
\text { Evening } \\
\text { Pick } 3 \\
\text { Sales }\end{array}$ & $\begin{array}{l}\text { Average } \\
\text { Evening } \\
\text { Pick } 4 \\
\text { Sales }\end{array}$ & $\begin{array}{l}\text { Average } \\
\text { Midday } \\
\text { Pick } 3 \\
\text { Sales }\end{array}$ & $\begin{array}{l}\text { Average } \\
\text { Midday } \\
\text { Pick } 4 \\
\text { Sales }\end{array}$ & $\begin{array}{l}\text { Number of } \\
\text { Obs. }\end{array}$ \\
\hline 6 & 0.143 & $\begin{array}{ll} & 0.571\end{array}$ & $\begin{array}{ll}1.750 \\
\end{array}$ & $\$ 875,652$ & $\$ 505,720$ & $\$ 479,814$ & $\$ 236,974$ & 32 \\
\hline 5 & 0.167 & $\$ 0.583$ & $\$ 1.714$ & $\$ 851,886$ & $\$ 490,480$ & $\$ 453,201$ & $\$ 224,080$ & 32 \\
\hline 4 & 0.200 & $\$ 0.600$ & $\begin{array}{ll}1.667 \\
\end{array}$ & $\$ 880,228$ & $\$ 505,948$ & $\$ 465,607$ & $\$ 230,911$ & 27 \\
\hline 3 & 0.250 & $\$ 0.625$ & $\$ 1.600$ & $\$ 878,987$ & $\$ 496,745$ & $\$ 464,746$ & $\$ 228,672$ & 23 \\
\hline 2 & 0.333 & \$ 0.667 & $\$ 1.500$ & $\$ 865,947$ & $\$ 479,331$ & \$ 439,519 & $\$ 215,834$ & 12 \\
\hline 1 & 0.500 & $\begin{array}{ll}\$ & 0.750\end{array}$ & $\begin{array}{ll}1.333 \\
\end{array}$ & $\$ 967,209$ & $\$ 507,490$ & $\$ 458,026$ & $\$ 221,416$ & 7 \\
\hline 0 & 1.000 & $\$ 1.000$ & $\$ 1.000$ & $\$ 993,718$ & $\$ 533,316$ & $\$ 481,413$ & $\$ 234,405$ & 2 \\
\hline $\begin{array}{l}\text { During } \\
\text { Promotion }\end{array}$ & 0.226 & $\$ 0.613$ & $\$ 1.644$ & $\$ 877,136$ & $\$ 498,779$ & $\$ 463,409$ & $\$ 228,567$ & 135 \\
\hline \multicolumn{2}{|c|}{ Outside of Promotion } & $\$ \quad 0.500$ & $\$ 2.000$ & $\$ 785,896$ & $\$ 482,490$ & $\$ 437,463$ & $\$ 221,705$ & 1605 \\
\hline \multicolumn{2}{|c|}{ Entire Sample } & & & $\$ 792,917$ & $\$ 483,727$ & $\$ 439,487$ & $\$ 222,247$ & 1740 \\
\hline \multicolumn{2}{|c|}{$\begin{array}{l}\text { The day after a Green } \\
\text { Ball is drawn with } 6 \\
\text { white balls }\end{array}$} & $\$ \quad 0.571$ & $\$ 1.750$ & $\$ 882,777$ & $\$ 505,149$ & $\$ 486,197$ & $\$ 238,812$ & 28 \\
\hline \multicolumn{2}{|c|}{$\begin{array}{l}\text { Not on a day after a } \\
\text { Green Ball is drawn } \\
\text { with } 6 \text { white balls }\end{array}$} & $\$ 0.571$ & $\$ 1.750$ & $\$ 825,781$ & $\$ 509,717$ & $\$ 435,131$ & $\$ 224,102$ & $\overline{4}$ \\
\hline
\end{tabular}


Table 2

The expected value and price of Pick 4 lottery tickets vary with the number of white balls during a Red Ball promotion

\begin{tabular}{|c|c|c|c|c|c|c|c|c|}
\hline $\begin{array}{l}\text { Number } \\
\text { of White } \\
\text { Balls }\end{array}$ & $\begin{array}{l}\text { Odds of a } \\
\text { Red Ball }\end{array}$ & $\begin{array}{l}\text { Expected } \\
\text { Value of a } \\
\text { Dollar Bet }\end{array}$ & $\begin{array}{l}\text { Cost of a } \\
\text { Dollar of } \\
\text { Expected } \\
\text { Winnings }\end{array}$ & $\begin{array}{l}\text { Average } \\
\text { Evening } \\
\text { Pick } 3 \\
\text { Sales }\end{array}$ & $\begin{array}{l}\text { Average } \\
\text { Evening } \\
\text { Pick } 4 \\
\text { Sales }\end{array}$ & $\begin{array}{l}\text { Average } \\
\text { Midday } \\
\text { Pick } 3 \\
\text { Sales }\end{array}$ & $\begin{array}{l}\text { Average } \\
\text { Midday } \\
\text { Pick } 4 \\
\text { Sales }\end{array}$ & $\begin{array}{l}\text { Number of } \\
\text { Obs. }\end{array}$ \\
\hline 6 & 0.143 & $\$ \quad 0.571$ & $\$ 1.750$ & $\$ 763,079$ & $\$ 521,857$ & $\$ 441,022$ & $\$ 235,152$ & 21 \\
\hline 5 & 0.167 & $\$ 0.583$ & $\$ 1.714$ & $\$ 700,866$ & $\$ 480,210$ & $\$ 411,658$ & $\$ 218,829$ & 19 \\
\hline 4 & 0.200 & $\$ \quad 0.600$ & $\$ 1.667$ & $\$ 767,934$ & $\$ 535,439$ & $\$ 428,083$ & $\$ 229,850$ & $\overline{14}$ \\
\hline 3 & 0.250 & $\$ 0.625$ & $\$ 1.600$ & $\$ 813,635$ & $\$ 574,409$ & $\$ 448,025$ & $\$ 240,729$ & 12 \\
\hline 2 & 0.333 & $\$ 0.667$ & $\$ 1.500$ & $\$ 794,822$ & $\$ 562,914$ & $\$ 449,580$ & $\$ 239,262$ & 10 \\
\hline 1 & 0.500 & $\$ 0.750$ & $\$ 1.333$ & $\$ 759,627$ & $\$ 559,526$ & $\$ 435,400$ & $\$ 232,977$ & 6 \\
\hline 0 & 1.000 & $\$ 1.000$ & $\$ 1.000$ & $\$ 798,723$ & $\$ 708,523$ & $\$ 442,384$ & $\$ 240,922$ & 2 \\
\hline $\begin{array}{l}\text { During } \\
\text { Promotion }\end{array}$ & 0.242 & $\$ 0.621$ & \$ 1.629 & $\$ 761,419$ & $\$ 534,231$ & $\$ 433,874$ & $\$ 231,844$ & $\overline{84}$ \\
\hline \multicolumn{2}{|c|}{ Outside of Promotion } & $\$ 0.500$ & $\$ 2.000$ & $\$ 794,576$ & $\$ 481,193$ & $\$ 439,760$ & $\$ 221,749$ & 1656 \\
\hline \multicolumn{2}{|c|}{ Entire Sample } & & & $\$ 792,917$ & $\$ 483,727$ & $\$ 439,487$ & $\$ 222,247$ & 1740 \\
\hline \multicolumn{2}{|c|}{$\begin{array}{l}\text { The day after a Red } \\
\text { Ball is drawn with } 6 \\
\text { white balls }\end{array}$} & $\$ 0.571$ & $\$ 1.750$ & $\$ 761,909$ & $\$ 523,200$ & $\$ 444,150$ & $\$ 237,083$ & $\overline{18}$ \\
\hline \multicolumn{2}{|c|}{$\begin{array}{l}\text { Not on a day after a } \\
\text { Red Ball is drawn with } \\
6 \text { white balls }\end{array}$} & $\$ 0.571$ & $\$ 1.750$ & $\$ 770,098$ & $\$ 513,799$ & $\$ 422,252$ & $\$ 223,566$ & 3 \\
\hline
\end{tabular}


Table 3

Descriptive statistics $(\mathrm{n}=1,739) *$

\begin{tabular}{|c|c|c|c|c|}
\hline & Mean & Maximum & Minimum & Std. Dev. \\
\hline Evening Pick 3 Sales & $\$ 792,883$ & $\$ 1,082,122$ & $\$ 447,325$ & $\$ 86,351$ \\
\hline Evening Pick 4 Sales & $\$ 483,709$ & $\$ 809,328$ & $\$ 241,487$ & $\$ 55,443$ \\
\hline Midday Pick 3 Sales & $\$ 439,427$ & $\$ 561,467$ & $\$ 185,230$ & $\$ 42,191$ \\
\hline Midday Pick 4 Sales & $\$ 222,217$ & $\$ 578,795$ & $\$ 88,124$ & $\$ 22,839$ \\
\hline Instant Games Sales & $\$ 3,261,100$ & $\$ 5,504,193$ & $\$ 1,457,700$ & $\$ 436,590$ \\
\hline $\begin{array}{l}\text { Evening Pick } 3 \text { Sales + Evening Pick } 4 \\
\text { Sales + Midday Pick } 3 \text { Sales + Midday } \\
\text { Pick } 4 \text { Sales + Instant Games Sales }\end{array}$ & $\$ 5,199,336$ & $\$ 7,452,067$ & $\$ 2,700,558$ & $\$ 574,622$ \\
\hline Price of Evening Pick 3 & $\$ 1.97$ & $\$ 2.00$ & $\$ 1.00$ & $\$ 0.102$ \\
\hline Price of Evening Pick 4 & $\$ 1.98$ & $\$ 2.00$ & $\$ 1.00$ & $\$ 0.086$ \\
\hline $\begin{array}{l}\text { Dummy Variable for Day After Green } \\
\text { Ball is Drawn }\end{array}$ & 0.020 & 1 & 0 & 0.141 \\
\hline $\begin{array}{l}\text { Dummy Variable for Day After Red Ball } \\
\text { is Drawn }\end{array}$ & 0.011 & 1 & 0 & 0.104 \\
\hline $\begin{array}{l}\text { Dummy Variable for the first } 75 \text { days } \\
\text { after the end of a Green Ball Promotion }\end{array}$ & 0.182 & 1 & 0 & 0.386 \\
\hline $\begin{array}{l}75 \text { Minus Number of Days Since End of } \\
\text { Green Ball Promotion (for } 75 \text { days) }\end{array}$ & 6.64 & 75 & 0 & 16.94 \\
\hline $\begin{array}{l}\text { Dummy Variable for the first } 75 \text { days } \\
\text { after the end of a Red Ball Promotion }\end{array}$ & 0.129 & 1 & 0 & 0.336 \\
\hline $\begin{array}{l}75 \text { Minus Number of Days Since End of } \\
\text { Red Ball Promotion (for } 75 \text { days) }\end{array}$ & 4.92 & 75 & 0 & 14.95 \\
\hline First 5 Days of Month Dummy & 0.164 & 1 & 0 & 0.371 \\
\hline Last 5 Days of Month Dummy & 0.164 & 1 & 0 & 0.370 \\
\hline Mega Millions Jackpot (in millions) & $\$ 62.4$ & $\$ 370$ & $\$ 10$ & $\$ 58.0$ \\
\hline $\begin{array}{l}\text { Evening Pick } 3 \text { Straight Parimutuel Prize } \\
\text { Payments }\end{array}$ & $\$ 260.84$ & $\$ 430.50$ & $\$ 72.00$ & $\$ 52.14$ \\
\hline $\begin{array}{l}\text { Midday Pick } 3 \text { Straight Parimutuel Prize } \\
\text { Payments }\end{array}$ & $\$ 262.85$ & $\$ 455.00$ & $\$ 99.00$ & $\$ 53.87$ \\
\hline $\begin{array}{l}\text { Evening Pick } 4 \text { Straight Parimutuel Prize } \\
\text { Payments }\end{array}$ & $\$ 2,722.19$ & $\$ 7,782.00$ & $\$ 646.00$ & $\$ 733.95$ \\
\hline $\begin{array}{l}\text { Midday Pick } 4 \text { Straight Parimutuel Prize } \\
\text { Payments }\end{array}$ & $\$ 2,758.85$ & $\$ 6,398.50$ & $\$ 394.50$ & $\$ 749.18$ \\
\hline $\begin{array}{l}\text { New Jersey Unemployment Rate- } \\
\text { Seasonally Adjusted }\end{array}$ & 4.9 & 8.4 & 4.2 & 0.95 \\
\hline Average Daily Gas Price & $\$ 2.45$ & $\$ 3.99$ & $\$ 1.45$ & $\$ 0.59$ \\
\hline Daily Precipitation in Newark (inches) & 0.13 & 6.18 & 0 & 0.40 \\
\hline
\end{tabular}

* Recall that Models 1-4 had one additional case. 
Table 4

Estimated demand for Pick 3 and Pick 4 New Jersey lottery tickets

\begin{tabular}{|c|c|c|c|c|}
\hline & $\begin{array}{l}\text { MODEL 1 } \\
\text { Log (Evening } \\
\text { Pick } 3 \text { Sales) }\end{array}$ & $\begin{array}{l}\frac{\text { MODEL 2 }}{\text { Log (Evening }} \\
\text { Pick } 4 \text { Sales) }\end{array}$ & $\begin{array}{l}\text { MODEL 3 } \\
\text { Log (Midday } \\
\text { Pick } 3 \text { Sales) }\end{array}$ & $\begin{array}{l}\text { MODEL } 4 \\
\text { Log (Midday } \\
\text { Pick } 4 \text { Sales) }\end{array}$ \\
\hline Constant & $\begin{array}{c}13.665 * * * \\
(0.051)\end{array}$ & $\begin{array}{c}13.251 * * * \\
(0.054)\end{array}$ & $\begin{array}{c}12.892 * * * \\
(0.049)\end{array}$ & $\begin{array}{c}12.236 * * * \\
(0.042)\end{array}$ \\
\hline Log (Pick 3 Evening Price) & $\begin{array}{c}-0.471^{* * *} \\
(0.042)\end{array}$ & $\begin{array}{c}-0.129 * * * \\
(0.025)\end{array}$ & $\begin{array}{c}-0.176 * * * \\
(0.035)\end{array}$ & $\begin{array}{l}-0.055^{*} \\
(0.033)\end{array}$ \\
\hline Log (Pick 4 Evening Price) & $\begin{array}{c}0.032 \\
(0.031) \\
\end{array}$ & $\begin{array}{c}-0.523 * * * \\
(0.031) \\
\end{array}$ & $\begin{array}{c}0.076 * * * \\
(0.027) \\
\end{array}$ & $\begin{array}{c}-0.085 * * * \\
(0.019) \\
\end{array}$ \\
\hline $\begin{array}{l}\text { Dummy Variable for Day After a } \\
\text { Green Ball is Drawn }\end{array}$ & $\begin{array}{l}0.049 * * * \\
(0.009)\end{array}$ & $\begin{array}{c}0.032 * * * \\
(0.008)\end{array}$ & $\begin{array}{c}0.054 * * * \\
(0.010)\end{array}$ & $\begin{array}{c}0.039 * * * \\
(0.009)\end{array}$ \\
\hline $\begin{array}{l}\text { Dummy Variable for Day After a Red } \\
\text { Ball is Drawn }\end{array}$ & $\begin{array}{c}-0.025 * * * \\
(0.008)\end{array}$ & $\begin{array}{c}0.008 \\
(0.010)\end{array}$ & $\begin{array}{c}-0.021 * * \\
(0.009)\end{array}$ & $\begin{array}{c}0.003 \\
(0.010)\end{array}$ \\
\hline $\begin{array}{l}\text { Dummy Variable for the first } 75 \text { days } \\
\text { after the end of a Green Ball } \\
\text { Promotion }\end{array}$ & $\begin{array}{l}0.078 * * * \\
(0.005)\end{array}$ & $\begin{array}{l}0.036 * * * \\
(0.005)\end{array}$ & $\begin{array}{l}0.065 * * * \\
(0.005)\end{array}$ & $\begin{array}{l}0.034 * * * \\
(0.005)\end{array}$ \\
\hline $\begin{array}{l}75 \text { Minus Number of Days after } \\
\text { Green Ball Promotion (for } 75 \text { days) }\end{array}$ & $\begin{array}{c}0.001 * * * \\
(0.000)\end{array}$ & $\begin{array}{c}0.001 * * * \\
(0.000) \\
\end{array}$ & $\begin{array}{c}0.001 * * * \\
(0.000)\end{array}$ & $\begin{array}{c}1.32 \mathrm{E}-04 \\
(9.53 \mathrm{E}-05) \\
\end{array}$ \\
\hline $\begin{array}{l}\text { Dummy Variable for the first } 75 \text { days } \\
\text { after the end of a Red Ball Promotion }\end{array}$ & $\begin{array}{l}-0.003 \\
(0.007) \\
\end{array}$ & $\begin{array}{c}0.039 * * * \\
(0.007) \\
\end{array}$ & $\begin{array}{l}-0.009 \\
(0.009) \\
\end{array}$ & $\begin{array}{c}0.016 * * \\
(0.008) \\
\end{array}$ \\
\hline $\begin{array}{l}75 \text { Minus Number of Days after Red } \\
\text { Ball Promotion (for } 75 \text { days) }\end{array}$ & $\begin{array}{c}1.96 \mathrm{E}-04 \\
(1.29 \mathrm{E}-04) \\
\end{array}$ & $\begin{array}{c}0.001 * * * \\
(0.000) \\
\end{array}$ & $\begin{array}{c}2.29 \mathrm{E}-04 \\
(1.83 \mathrm{E}-04) \\
\end{array}$ & $\begin{array}{c}0.001 * * * \\
(0.000) \\
\end{array}$ \\
\hline First 5 Days of the Month Dummy & $\begin{array}{c}0.045^{* * * *} \\
(0.003) \\
\end{array}$ & $\begin{array}{c}0.039 * * * \\
(0.004) \\
\end{array}$ & $\begin{array}{c}0.044 * * * \\
(0.004) \\
\end{array}$ & $\begin{array}{c}0.041 * * * \\
(0.004) \\
\end{array}$ \\
\hline Last 5 Days of the Month Dummy & $\begin{array}{l}-0.003 \\
(0.003)\end{array}$ & $\begin{array}{c}0.002 \\
(0.004)\end{array}$ & $\begin{array}{l}-0.006 \\
(0.004)\end{array}$ & $\begin{array}{l}-0.002 \\
(0.004)\end{array}$ \\
\hline Monday Dummy & $\begin{array}{c}0.192 * * * \\
(0.004) \\
\end{array}$ & $\begin{array}{c}0.239 * * * \\
(0.005) \\
\end{array}$ & $\begin{array}{c}0.056 * * * \\
(0.004) \\
\end{array}$ & $\begin{array}{c}0.088 * * * \\
(0.005) \\
\end{array}$ \\
\hline Tuesday Dummy & $\begin{array}{c}0.152 * * * \\
(0.005) \\
\end{array}$ & $\begin{array}{c}0.173 * * * \\
(0.005) \\
\end{array}$ & $\begin{array}{c}0.061 * * * \\
(0.005) \\
\end{array}$ & $\begin{array}{c}0.076 * * * \\
(0.005) \\
\end{array}$ \\
\hline Wednesday Dummy & $\begin{array}{c}0.156^{* * * *} \\
(0.004) \\
\end{array}$ & $\begin{array}{c}0.164 * * * \\
(0.005) \\
\end{array}$ & $\begin{array}{c}0.070 * * * \\
(0.005) \\
\end{array}$ & $\begin{array}{c}0.081 * * * \\
(0.006) \\
\end{array}$ \\
\hline Thursday Dummy & $\begin{array}{c}0.239 * * * \\
(0.004) \\
\end{array}$ & $\begin{array}{c}0.262 * * * \\
(0.004) \\
\end{array}$ & $\begin{array}{c}0.122 * * * \\
(0.005) \\
\end{array}$ & $\begin{array}{c}0.136 * * * \\
(0.005) \\
\end{array}$ \\
\hline Friday Dummy & $\begin{array}{l}0.315 * * * \\
(0.005) \\
\end{array}$ & $\begin{array}{c}0.330 * * * \\
(0.006) \\
\end{array}$ & $\begin{array}{c}0.209 * * * \\
(0.005) \\
\end{array}$ & $\begin{array}{c}0.227 * * * \\
(0.007) \\
\end{array}$ \\
\hline Saturday Dummy & $\begin{array}{c}0.199 * * * \\
(0.004)\end{array}$ & $\begin{array}{c}0.197 * * * \\
(0.005)\end{array}$ & $\begin{array}{c}0.188 * * * \\
(0.005)\end{array}$ & $\begin{array}{c}0.185 * * * \\
(0.005)\end{array}$ \\
\hline $\begin{array}{l}\text { Log(Mega Millions jackpot in } \\
\text { millions) }\end{array}$ & $\begin{array}{c}0.005 * * * \\
(0.002)\end{array}$ & $\begin{array}{l}0.003 * \\
(0.002)\end{array}$ & $\begin{array}{c}0.002 \\
(0.002)\end{array}$ & $\begin{array}{l}-0.001 \\
(0.002)\end{array}$ \\
\hline $\begin{array}{l}\text { Pick } 3 \text { Evening Straight Parimutuel } \\
\text { Prize for the Previous Day }\end{array}$ & $\begin{array}{c}0.004 \\
(0.005)\end{array}$ & & $\begin{array}{c}0.002 \\
(0.004)\end{array}$ & \\
\hline
\end{tabular}




\begin{tabular}{|c|c|c|c|c|}
\hline $\begin{array}{l}\text { Pick } 3 \text { Midday Straight Parimutuel } \\
\text { Prize for the Previous Day }\end{array}$ & & & $\begin{array}{c}4.68 \mathrm{E}-04 \\
(4.20 \mathrm{E}-03) \\
\end{array}$ & \\
\hline $\begin{array}{l}\text { Pick } 3 \text { Midday Straight Parimutuel } \\
\text { Prize for that Day }\end{array}$ & $\begin{array}{l}-0.002 \\
(0.005)\end{array}$ & & & \\
\hline $\begin{array}{l}\text { Pick } 4 \text { Evening Straight Parimutuel } \\
\text { Prize for the Previous Day }\end{array}$ & & $\begin{array}{c}0.002 \\
(0.004) \\
\end{array}$ & & $\begin{array}{l}-0.006^{*} \\
(0.004)\end{array}$ \\
\hline $\begin{array}{l}\text { Pick } 4 \text { Midday Straight Parimutuel } \\
\text { Prize for the Previous Day }\end{array}$ & & & & $\begin{array}{c}0.005 \\
(0.004) \\
\end{array}$ \\
\hline $\begin{array}{l}\text { Pick } 4 \text { Midday Straight Parimutuel } \\
\text { Prize for that Day }\end{array}$ & & $\begin{array}{c}0.005 \\
(0.004) \\
\end{array}$ & & \\
\hline NJ Unemployment Rate SA & $\begin{array}{c}-0.010 * * * \\
(0.003) \\
\end{array}$ & $\begin{array}{l}-0.003 \\
(0.003) \\
\end{array}$ & $\begin{array}{c}-0.018 * * * \\
(0.003) \\
\end{array}$ & $\begin{array}{c}-0.008 * * * \\
(0.003) \\
\end{array}$ \\
\hline Log(Average Daily Gas Price) & $\begin{array}{c}-0.041 * * * \\
(0.012)\end{array}$ & $\begin{array}{c}-0.085 * * * \\
(0.012)\end{array}$ & $\begin{array}{l}-0.020^{*} \\
(0.012) \\
\end{array}$ & $\begin{array}{c}-0.051 * * * \\
(0.012) \\
\end{array}$ \\
\hline $\begin{array}{l}\text { Day Before Government Shutdown } \\
\text { Dummy }\end{array}$ & $\begin{array}{c}0.359 * * * \\
(0.005) \\
\end{array}$ & $\begin{array}{c}0.355 * * * \\
(0.006)\end{array}$ & $\begin{array}{c}0.258 * * * \\
(0.005) \\
\end{array}$ & $\begin{array}{c}0.255 * * * \\
(0.005) \\
\end{array}$ \\
\hline Daily Precipitation in Newark & $\begin{array}{c}-0.020 * * * \\
(0.003) \\
\end{array}$ & $\begin{array}{c}-0.019 * * * \\
(0.003) \\
\end{array}$ & $\begin{array}{c}-0.021 * * * \\
(0.004) \\
\end{array}$ & $\begin{array}{c}-0.020 * * * \\
(0.004) \\
\end{array}$ \\
\hline New Year's Day Dummy & $\begin{array}{c}-0.179 * * \\
(0.070) \\
\end{array}$ & $\begin{array}{c}-0.185 * * \\
(0.077) \\
\end{array}$ & $\begin{array}{l}-0.140^{*} \\
(0.079) \\
\end{array}$ & $\begin{array}{l}-0.154^{*} \\
(0.080) \\
\end{array}$ \\
\hline Day Before New Year's Day Dummy & $\begin{array}{l}-0.051 \\
(0.044) \\
\end{array}$ & $\begin{array}{l}-0.045 \\
(0.035) \\
\end{array}$ & $\begin{array}{l}-0.081 \\
(0.051) \\
\end{array}$ & $\begin{array}{l}-0.084 * \\
(0.044) \\
\end{array}$ \\
\hline Day After New Year's Day Dummy & $\begin{array}{c}0.081 * * \\
(0.038) \\
\end{array}$ & $\begin{array}{c}0.108 * * * \\
(0.042) \\
\end{array}$ & $\begin{array}{c}0.068 \\
(0.048) \\
\end{array}$ & $\begin{array}{c}0.075 \\
(0.048) \\
\end{array}$ \\
\hline Martin Luther King Holiday Dummy & $\begin{array}{c}-0.047 * * * \\
(0.018)\end{array}$ & $\begin{array}{l}-0.033 \\
(0.021) \\
\end{array}$ & $\begin{array}{c}-0.051 * * \\
(0.021) \\
\end{array}$ & $\begin{array}{c}-0.051 * * \\
(0.020) \\
\end{array}$ \\
\hline $\begin{array}{l}\text { Day Before Martin Luther King } \\
\text { Holiday Dummy }\end{array}$ & $\begin{array}{l}-0.015 \\
(0.010)\end{array}$ & $\begin{array}{c}-0.013 * * \\
(0.006)\end{array}$ & $\begin{array}{c}-0.033 * * * \\
(0.012)\end{array}$ & $\begin{array}{c}-0.038 * * * \\
(0.010)\end{array}$ \\
\hline $\begin{array}{l}\text { Day After Martin Luther King } \\
\text { Holiday Dummy }\end{array}$ & $\begin{array}{l}-0.025 \\
(0.023) \\
\end{array}$ & $\begin{array}{l}-0.030 \\
(0.020) \\
\end{array}$ & $\begin{array}{l}-0.025 \\
(0.030) \\
\end{array}$ & $\begin{array}{l}-0.040 \\
(0.025) \\
\end{array}$ \\
\hline Lincoln's Birthday Holiday Dummy & $\begin{array}{c}0.019 \\
(0.016) \\
\end{array}$ & $\begin{array}{c}0.019 \\
(0.015) \\
\end{array}$ & $\begin{array}{c}0.042 * * * \\
(0.014) \\
\end{array}$ & $\begin{array}{c}0.044 * * * \\
(0.008)\end{array}$ \\
\hline $\begin{array}{l}\text { Day Before Lincoln's Birthday } \\
\text { Holiday Dummy }\end{array}$ & $\begin{array}{l}0.035 * * \\
(0.016)\end{array}$ & $\begin{array}{l}0.036 * * \\
(0.015)\end{array}$ & $\begin{array}{c}0.036 \\
(0.025)\end{array}$ & $\begin{array}{l}0.039 * \\
(0.021)\end{array}$ \\
\hline $\begin{array}{l}\text { Day After Lincoln's Birthday Holiday } \\
\text { Dummy }\end{array}$ & $\begin{array}{c}0.027 * * * \\
(0.008) \\
\end{array}$ & $\begin{array}{c}0.028 * * * \\
(0.010) \\
\end{array}$ & $\begin{array}{l}0.034 * * \\
(0.014) \\
\end{array}$ & $\begin{array}{c}0.037 * * \\
(0.015) \\
\end{array}$ \\
\hline $\begin{array}{l}\text { Washington's Birthday Holiday } \\
\text { Dummy }\end{array}$ & $\begin{array}{c}-0.039 * * \\
(0.020) \\
\end{array}$ & $\begin{array}{l}-0.037 * \\
(0.020)\end{array}$ & $\begin{array}{l}-0.015 \\
(0.020)\end{array}$ & $\begin{array}{l}-0.015 \\
(0.020)\end{array}$ \\
\hline $\begin{array}{l}\text { Day Before Washington's Birthday } \\
\text { Holiday Dummy }\end{array}$ & $\begin{array}{c}0.026^{* *} \\
(0.010) \\
\end{array}$ & $\begin{array}{l}0.029 * * \\
(0.013)\end{array}$ & $\begin{array}{l}-0.003 \\
(0.011) \\
\end{array}$ & $\begin{array}{l}-0.001 \\
(0.013) \\
\end{array}$ \\
\hline $\begin{array}{l}\text { Day After Washington's Birthday } \\
\text { Holiday Dummy }\end{array}$ & $\begin{array}{l}0.025^{*} \\
(0.015) \\
\end{array}$ & $\begin{array}{c}0.025 \\
(0.023) \\
\end{array}$ & $\begin{array}{c}0.020 \\
(0.013) \\
\end{array}$ & $\begin{array}{c}0.029 \\
(0.020) \\
\end{array}$ \\
\hline Good Friday Holiday Dummy & $\begin{array}{c}-0.029 * * * \\
(0.009)\end{array}$ & $\begin{array}{c}-0.034 * * * \\
(0.008)\end{array}$ & $\begin{array}{c}0.002 \\
(0.008) \\
\end{array}$ & $\begin{array}{l}-0.014^{*} \\
(0.007) \\
\end{array}$ \\
\hline $\begin{array}{l}\text { Day Before Good Friday Holiday } \\
\text { Dummy }\end{array}$ & $\begin{array}{c}0.021 \\
(0.017) \\
\end{array}$ & $\begin{array}{c}0.006 \\
(0.014) \\
\end{array}$ & $\begin{array}{r}0.022 \\
(0.015) \\
\end{array}$ & $\begin{array}{r}0.012 \\
(0.011) \\
\end{array}$ \\
\hline $\begin{array}{l}\text { Day After Good Friday Holiday } \\
\text { Dummy }\end{array}$ & $\begin{array}{c}0.022 * * * \\
(0.008) \\
\end{array}$ & $\begin{array}{l}0.021 * * \\
(0.009)\end{array}$ & $\begin{array}{c}0.035 * * * \\
(0.008) \\
\end{array}$ & $\begin{array}{c}0.028 * * * \\
(0.007) \\
\end{array}$ \\
\hline Memorial Day Holiday Dummy & $\begin{array}{c}-0.199 * * * \\
(0.011)\end{array}$ & $\begin{array}{c}-0.215 * * * \\
(0.009)\end{array}$ & $\begin{array}{c}-0.072 * * * \\
(0.012)\end{array}$ & $\begin{array}{c}-0.104 * * * \\
(0.010) \\
\end{array}$ \\
\hline $\begin{array}{l}\text { Day Before Memorial Day Holiday } \\
\text { Dummy }\end{array}$ & $\begin{array}{c}-0.032 * * * \\
(0.007)\end{array}$ & $\begin{array}{c}-0.029 * * * \\
(0.009)\end{array}$ & $\begin{array}{c}-0.067 * * * \\
(0.014)\end{array}$ & $\begin{array}{c}-0.061 * * * \\
(0.010)\end{array}$ \\
\hline
\end{tabular}




\begin{tabular}{|c|c|c|c|c|}
\hline $\begin{array}{l}\text { Day After Memorial Day Holiday } \\
\text { Dummy }\end{array}$ & $\begin{array}{l}-0.033^{*} \\
(0.018) \\
\end{array}$ & $\begin{array}{c}-0.048 * * \\
(0.024) \\
\end{array}$ & $\begin{array}{l}-0.001 \\
(0.014) \\
\end{array}$ & $\begin{array}{l}-0.013 \\
(0.019) \\
\end{array}$ \\
\hline Independence Day Holiday Dummy & $\begin{array}{c}-0.145^{* * *} \\
(0.051)\end{array}$ & $\begin{array}{c}-0.168 * * * \\
(0.051)\end{array}$ & $\begin{array}{c}-0.065 * * * \\
(0.014)\end{array}$ & $\begin{array}{c}-0.088 * * * \\
(0.018)\end{array}$ \\
\hline $\begin{array}{l}\text { Day Before Independence Day } \\
\text { Holiday Dummy }\end{array}$ & $\begin{array}{l}-0.011 \\
(0.017)\end{array}$ & $\begin{array}{l}-0.020^{*} \\
(0.011)\end{array}$ & $\begin{array}{l}-0.022 \\
(0.018) \\
\end{array}$ & $\begin{array}{l}-0.032^{*} \\
(0.018) \\
\end{array}$ \\
\hline $\begin{array}{l}\text { Day After Independence Day Holiday } \\
\text { Dummy }\end{array}$ & $\begin{array}{l}-0.027 \\
(0.054)\end{array}$ & $\begin{array}{l}-0.051 \\
(0.060)\end{array}$ & $\begin{array}{c}0.027 \\
(0.025)\end{array}$ & $\begin{array}{c}0.007 \\
(0.029) \\
\end{array}$ \\
\hline Labor Day Holiday Dummy & $\begin{array}{c}-0.153 * * * \\
(0.013) \\
\end{array}$ & $\begin{array}{c}-0.169 * * * \\
(0.014)\end{array}$ & $\begin{array}{c}-0.058 * * * \\
(0.015) \\
\end{array}$ & $\begin{array}{c}-0.077 * * * \\
(0.011) \\
\end{array}$ \\
\hline $\begin{array}{l}\text { Day Before Labor Day Holiday } \\
\text { Dummy }\end{array}$ & $\begin{array}{l}-0.010 \\
(0.012) \\
\end{array}$ & $\begin{array}{l}-0.013 \\
(0.015) \\
\end{array}$ & $\begin{array}{c}-0.044 * * * \\
(0.011) \\
\end{array}$ & $\begin{array}{c}-0.052 * * * \\
(0.013) \\
\end{array}$ \\
\hline $\begin{array}{l}\text { Day After Labor Day Holiday } \\
\text { Dummy }\end{array}$ & $\begin{array}{c}0.014 \\
(0.026) \\
\end{array}$ & $\begin{array}{l}-0.019 \\
(0.019) \\
\end{array}$ & $\begin{array}{c}0.001 \\
(0.012) \\
\end{array}$ & $\begin{array}{l}-0.014 \\
(0.017) \\
\end{array}$ \\
\hline Columbus Day Holiday Dummy & $\begin{array}{c}-0.037 * * \\
(0.017) \\
\end{array}$ & $\begin{array}{l}-0.029 \\
(0.025) \\
\end{array}$ & $\begin{array}{c}-0.043 * * * \\
(0.012) \\
\end{array}$ & $\begin{array}{c}-0.037 * * \\
(0.015) \\
\end{array}$ \\
\hline $\begin{array}{l}\text { Day Before Columbus Day Holiday } \\
\text { Dummy }\end{array}$ & $\begin{array}{l}-0.004 \\
(0.008) \\
\end{array}$ & $\begin{array}{c}4.30 \mathrm{E}-04 \\
(1.45 \mathrm{E}-02) \\
\end{array}$ & $\begin{array}{c}-0.020 * * * \\
(0.007) \\
\end{array}$ & $\begin{array}{c}-0.026 * * * \\
(0.008) \\
\end{array}$ \\
\hline $\begin{array}{l}\text { Day After Columbus Day Holiday } \\
\text { Dummy }\end{array}$ & $\begin{array}{l}-0.006 \\
(0.014) \\
\end{array}$ & $\begin{array}{l}-0.001 \\
(0.021) \\
\end{array}$ & $\begin{array}{l}-0.009 \\
(0.013) \\
\end{array}$ & $\begin{array}{l}-0.002 \\
(0.018)\end{array}$ \\
\hline Election Day Dummy & $\begin{array}{c}0.041 * * * \\
(0.010)\end{array}$ & $\begin{array}{c}0.041 * * * \\
(0.013) \\
\end{array}$ & $\begin{array}{c}0.043 * * * \\
(0.013)\end{array}$ & $\begin{array}{c}0.051 * * * \\
(0.015)\end{array}$ \\
\hline Day Before Election Day Dummy & $\begin{array}{c}0.001 \\
(0.009) \\
\end{array}$ & $\begin{array}{c}0.016 \\
(0.010) \\
\end{array}$ & $\begin{array}{c}0.013 \\
(0.012) \\
\end{array}$ & $\begin{array}{l}0.024^{*} \\
(0.013) \\
\end{array}$ \\
\hline Day After Election Day Dummy & $\begin{array}{c}0.016 \\
(0.021) \\
\end{array}$ & $\begin{array}{c}0.029 \\
(0.021) \\
\end{array}$ & $\begin{array}{c}0.016 \\
(0.022) \\
\end{array}$ & $\begin{array}{c}0.026 \\
(0.024)\end{array}$ \\
\hline Veterans Day Holiday Dummy & $\begin{array}{c}-0.023 * * * \\
(0.006) \\
\end{array}$ & $\begin{array}{c}0.002 \\
(0.010) \\
\end{array}$ & $\begin{array}{c}-0.023 * * * \\
(0.008) \\
\end{array}$ & $\begin{array}{l}-0.006 \\
(0.011) \\
\end{array}$ \\
\hline $\begin{array}{l}\text { Day Before Veterans Day Holiday } \\
\text { Dummy }\end{array}$ & $\begin{array}{l}-0.011 \\
(0.007)\end{array}$ & $\begin{array}{l}-0.003 \\
(0.006)\end{array}$ & $\begin{array}{c}-0.019 * * \\
(0.008)\end{array}$ & $\begin{array}{c}-0.017 * * * \\
(0.008)\end{array}$ \\
\hline $\begin{array}{l}\text { Day After Veterans Day Holiday } \\
\text { Dummy }\end{array}$ & $\begin{array}{l}-0.010 \\
(0.016) \\
\end{array}$ & $\begin{array}{c}0.007 \\
(0.016) \\
\end{array}$ & $\begin{array}{l}-0.010 \\
(0.016) \\
\end{array}$ & $\begin{array}{c}0.004 \\
(0.017) \\
\end{array}$ \\
\hline Thanksgiving Day Holiday Dummy & $\begin{array}{c}-0.338 * * * \\
(0.026) \\
\end{array}$ & $\begin{array}{c}-0.345 * * * \\
(0.036)\end{array}$ & $\begin{array}{c}-0.081 * * * \\
(0.020)\end{array}$ & $\begin{array}{c}-0.083 * * * \\
(0.027)\end{array}$ \\
\hline $\begin{array}{l}\text { Day Before Thanksgiving Day } \\
\text { Holiday Dummy }\end{array}$ & $\begin{array}{c}-0.097 * * * \\
(0.010) \\
\end{array}$ & $\begin{array}{c}-0.104 * * * \\
(0.014) \\
\end{array}$ & $\begin{array}{c}-0.103 * * * \\
(0.017) \\
\end{array}$ & $\begin{array}{c}-0.115^{* * *} \\
(0.015) \\
\end{array}$ \\
\hline $\begin{array}{l}\text { Day After Thanksgiving Day Holiday } \\
\text { Dummy }\end{array}$ & $\begin{array}{l}0.120 * * * \\
(0.011)\end{array}$ & $\begin{array}{l}0.140 * * * \\
(0.014)\end{array}$ & $\begin{array}{c}0.099 * * * \\
(0.010)\end{array}$ & $\begin{array}{l}0.113 * * * \\
(0.009)\end{array}$ \\
\hline Trend & $\begin{array}{c}-1.70 \mathrm{E}-05 * * * \\
(5.85 \mathrm{E}-06) \\
\end{array}$ & $\begin{array}{l}-4.64 \mathrm{E}-06 \\
(5.84 \mathrm{E}-06) \\
\end{array}$ & $\begin{array}{c}8.64 \mathrm{E}-05 * * * \\
(6.44 \mathrm{E}-06) \\
\end{array}$ & $\begin{array}{c}9.83 \mathrm{E}-05 * * * \\
(5.80 \mathrm{E}-06) \\
\end{array}$ \\
\hline $\operatorname{AR}(1)$ & $\begin{array}{c}0.2435 * * * \\
(0.0427) \\
\end{array}$ & $\begin{array}{c}0.125^{* * *} \\
(0.046) \\
\end{array}$ & $\begin{array}{c}0.376^{* * *} \\
(0.061) \\
\end{array}$ & $\begin{array}{c}0.245 * * * \\
(0.055) \\
\end{array}$ \\
\hline R-squared & 0.858 & 0.807 & 0.807 & 0.757 \\
\hline Adjusted R-squared & 0.852 & 0.800 & 0.800 & 0.748 \\
\hline F-Statistic & 164.2 & 114.1 & 113.8 & 84.9 \\
\hline Durbin-Watson statistic & 2.08 & 2.03 & 2.16 & 2.10 \\
\hline
\end{tabular}

***Statistically significant at the .01 level; **Statistically significant at the .05 level; *Statistically significant at the .10 level. Robust standard errors in parentheses. 
Table 5

Percentage change in sales due to statistically significant non-holiday dummy variables*

\begin{tabular}{|c|c|c|c|c|}
\hline & $\begin{array}{l}\text { MODEL 1 } \\
\text { Percentage } \\
\text { Change in } \\
\text { Evening } \\
\text { Pick } 3 \text { Sales }\end{array}$ & $\begin{array}{l}\text { MODEL 2 } \\
\text { Percentage } \\
\text { Change in } \\
\text { Evening } \\
\text { Pick } 4 \text { Sales }\end{array}$ & $\begin{array}{l}\text { MODEL 3 } \\
\text { Percentage } \\
\text { Change in } \\
\text { Midday } \\
\text { Pick } 3 \text { Sales }\end{array}$ & $\begin{array}{l}\text { MODEL 4 } \\
\text { Percentage } \\
\text { Change in } \\
\text { Midday } \\
\text { Pick } 4 \text { Sales }\end{array}$ \\
\hline $\begin{array}{l}\text { Dummy Variable for Day after a } \\
\text { Green Ball is drawn }\end{array}$ & $5 \%$ & $3.3 \%$ & $5.6 \%$ & $4 \%$ \\
\hline $\begin{array}{l}\text { Dummy Variable for Day after a } \\
\text { Red Ball is drawn }\end{array}$ & $-2.4 \%$ & & $-2.1 \%$ & \\
\hline $\begin{array}{l}\text { Dummy Variable for the first } 75 \\
\text { days after the end of a Green Ball } \\
\text { Promotion }\end{array}$ & $8.1 \%$ & $3.6 \%$ & $6.7 \%$ & $3.4 \%$ \\
\hline $\begin{array}{l}\text { Dummy Variable for the first } 75 \\
\text { days after the end of a Red Ball } \\
\text { Promotion }\end{array}$ & & $4 \%$ & & $1.6 \%$ \\
\hline $\begin{array}{l}\text { First } 5 \text { Days of the Month } \\
\text { Dummy }\end{array}$ & $4.6 \%$ & $4 \%$ & $4.5 \%$ & $4.2 \%$ \\
\hline Monday Dummy & $21.2 \%$ & $27 \%$ & $5.8 \%$ & $9.2 \%$ \\
\hline Tuesday Dummy & $16.4 \%$ & $18.9 \%$ & $6.3 \%$ & $7.9 \%$ \\
\hline Wednesday Dummy & $16.9 \%$ & $17.8 \%$ & $7.2 \%$ & $8.5 \%$ \\
\hline Thursday Dummy & $27 \%$ & $29.9 \%$ & $13 \%$ & $14.5 \%$ \\
\hline Friday Dummy & $37 \%$ & $39.1 \%$ & $23.2 \%$ & $25.4 \%$ \\
\hline Saturday Dummy & $22 \%$ & $21.8 \%$ & $20.7 \%$ & $20.3 \%$ \\
\hline $\begin{array}{l}\text { Day Before Government } \\
\text { Shutdown Dummy }\end{array}$ & $43.2 \%$ & $42.6 \%$ & $29.5 \%$ & $29 \%$ \\
\hline
\end{tabular}

*We only include statistically significant variables at the $95 \%$ confidence level here.

Note: These percentage changes were calculated as $\left(G\left(e^{B}-1\right) * \mathbf{1 0 0}\right)$, where $B$ is the dummy coefficient from the semilogarithmic regression, where sales are in logs and the regressor is a binary dummy variable. 
Table 6

Percentage change in sales due to statistically significant holiday dummy variables*

\begin{tabular}{|c|c|c|c|c|}
\hline & $\begin{array}{l}\text { MODEL 1 } \\
\text { Percentage } \\
\text { Change in } \\
\text { Evening } \\
\text { Pick } 3 \text { Sales }\end{array}$ & $\begin{array}{l}\text { MODEL 2 } \\
\text { Percentage } \\
\text { Change in } \\
\text { Evening } \\
\text { Pick } 4 \text { Sales }\end{array}$ & $\begin{array}{l}\text { MODEL } 3 \\
\text { Percentage } \\
\text { Change in } \\
\text { Midday } \\
\text { Pick } 3 \text { Sales }\end{array}$ & $\begin{array}{l}\text { MODEL } 4 \\
\text { Percentage } \\
\text { Change in } \\
\text { Midday } \\
\text { Pick } 4 \text { Sales }\end{array}$ \\
\hline New Year's Day Dummy & $-16.4 \%$ & $-16.9 \%$ & & \\
\hline \multicolumn{5}{|l|}{$\begin{array}{l}\text { Day Before New Year's Day } \\
\text { Dummy }\end{array}$} \\
\hline $\begin{array}{l}\text { Day After New Year's Day } \\
\text { Dummy }\end{array}$ & $8.4 \%$ & $11.4 \%$ & & \\
\hline $\begin{array}{l}\text { Martin Luther King Holiday } \\
\text { Dummy }\end{array}$ & $-4.6 \%$ & & $-5 \%$ & $-5 \%$ \\
\hline $\begin{array}{l}\text { Day Before Martin Luther King } \\
\text { Holiday Dummy }\end{array}$ & & $-1.3 \%$ & $-3.2 \%$ & $-3.7 \%$ \\
\hline \multicolumn{5}{|l|}{$\begin{array}{l}\text { Day After Martin Luther King } \\
\text { Holiday Dummy }\end{array}$} \\
\hline $\begin{array}{l}\text { Lincoln's Birthday Holiday } \\
\text { Dummy }\end{array}$ & & & $4.3 \%$ & $4.5 \%$ \\
\hline $\begin{array}{l}\text { Day Before Lincoln's Birthday } \\
\text { Holiday Dummy }\end{array}$ & $3.6 \%$ & $3.7 \%$ & & \\
\hline $\begin{array}{l}\text { Day After Lincoln's Birthday } \\
\text { Holiday Dummy }\end{array}$ & $2.8 \%$ & $2.9 \%$ & $3.5 \%$ & $3.8 \%$ \\
\hline $\begin{array}{l}\text { Washington's Birthday Holiday } \\
\text { Dummy }\end{array}$ & $-3.9 \%$ & & & \\
\hline $\begin{array}{l}\text { Day Before Washington's } \\
\text { Birthday Holiday Dummy }\end{array}$ & $2.6 \%$ & $2.9 \%$ & & \\
\hline \multicolumn{5}{|l|}{$\begin{array}{l}\text { Day After Washington's Birthday } \\
\text { Holiday Dummy }\end{array}$} \\
\hline Good Friday Holiday Dummy & $-2.8 \%$ & $-3.3 \%$ & & \\
\hline \multicolumn{5}{|l|}{$\begin{array}{l}\text { Day Before Good Friday Holiday } \\
\text { Dummy }\end{array}$} \\
\hline $\begin{array}{l}\text { Day After Good Friday Holiday } \\
\text { Dummy }\end{array}$ & $2.2 \%$ & $2.1 \%$ & $3.6 \%$ & $2.8 \%$ \\
\hline Memorial Day Holiday Dummy & $-18.1 \%$ & $-19.3 \%$ & $-6.9 \%$ & $-9.9 \%$ \\
\hline $\begin{array}{l}\text { Day Before Memorial Day } \\
\text { Holiday Dummy }\end{array}$ & $-3.2 \%$ & $-2.8 \%$ & $-6.5 \%$ & $-6 \%$ \\
\hline $\begin{array}{l}\text { Day After Memorial Day Holiday } \\
\text { Dummy }\end{array}$ & & $-4.7 \%$ & & \\
\hline $\begin{array}{l}\text { Independence Day Holiday } \\
\text { Dummy }\end{array}$ & $-13.5 \%$ & $-15.5 \%$ & $-6.3 \%$ & $-8.4 \%$ \\
\hline \multicolumn{5}{|l|}{$\begin{array}{l}\text { Day Before Independence Day } \\
\text { Holiday Dummy }\end{array}$} \\
\hline $\begin{array}{l}\text { Day After Independence Day } \\
\text { Holiday Dummy }\end{array}$ & & & & \\
\hline
\end{tabular}




\begin{tabular}{|c|c|c|c|c|}
\hline Labor Day Holiday Dummy & $-14.1 \%$ & $-15.5 \%$ & $-5.7 \%$ & $-7.4 \%$ \\
\hline $\begin{array}{l}\text { Day Before Labor Day Holiday } \\
\text { Dummy }\end{array}$ & & & $-4.3 \%$ & $-5.1 \%$ \\
\hline \multicolumn{5}{|l|}{$\begin{array}{l}\text { Day After Labor Day Holiday } \\
\text { Dummy }\end{array}$} \\
\hline Columbus Day Holiday Dummy & $-3.7 \%$ & & $-4.2 \%$ & $-3.6 \%$ \\
\hline $\begin{array}{l}\text { Day Before Columbus Day } \\
\text { Holiday Dummy }\end{array}$ & & & $-1.9 \%$ & $-2.5 \%$ \\
\hline \multicolumn{5}{|l|}{$\begin{array}{l}\text { Day After Columbus Day Holiday } \\
\text { Dummy }\end{array}$} \\
\hline Election Day Dummy & $4.2 \%$ & $4.2 \%$ & $4.4 \%$ & $5.2 \%$ \\
\hline \multicolumn{5}{|l|}{ Day Before Election Day Dummy } \\
\hline \multicolumn{5}{|l|}{ Day After Election Day Dummy } \\
\hline Veterans Day Holiday Dummy & $-2.3 \%$ & & $-2.3 \%$ & \\
\hline $\begin{array}{l}\text { Day Before Veterans Day Holiday } \\
\text { Dummy }\end{array}$ & & & $-1.9 \%$ & $-1.7 \%$ \\
\hline \multicolumn{5}{|l|}{$\begin{array}{l}\text { Day After Veterans Day Holiday } \\
\text { Dummy }\end{array}$} \\
\hline $\begin{array}{l}\text { Thanksgiving Day Holiday } \\
\text { Dummy }\end{array}$ & $-28.7 \%$ & $-29.2 \%$ & $-7.8 \%$ & $-8 \%$ \\
\hline $\begin{array}{l}\text { Day Before Thanksgiving Day } \\
\text { Holiday Dummy }\end{array}$ & $-9.3 \%$ & $-9.9 \%$ & $-9.8 \%$ & $-10.9 \%$ \\
\hline $\begin{array}{l}\text { Day After Thanksgiving Day } \\
\text { Holiday Dummy }\end{array}$ & $12.7 \%$ & $15 \%$ & $10.4 \%$ & $12 \%$ \\
\hline
\end{tabular}

*We only include statistically significant variables at the $95 \%$ confidence level here.

Note: These percentage changes were calculated as $\left.\left(C(e]^{D}-1\right) * \mathbf{1 0 0}\right)$, where $B$ is the dummy coefficient from the semilogarithmic regression, where sales are in logs and the regressor is a binary dummy variable. 
Table 7

Estimated demand for tickets of instant games and tickets of Pick $3+$ Pick $4+$ instant games

\begin{tabular}{|c|c|c|}
\hline & $\begin{array}{l}\frac{\text { MODEL } 5}{\text { Log (Instant }} \\
\text { Games Sales) }\end{array}$ & $\begin{array}{c}\frac{\text { MODEL 6 }}{\text { Log (Sales of all }} \\
\text { Pick } 3+\text { all Pick } 4+ \\
\text { Instant) }\end{array}$ \\
\hline Constant & $\begin{array}{c}14.951 * * * \\
(0.062)\end{array}$ & $\begin{array}{c}15.455 * * * \\
(0.042)\end{array}$ \\
\hline Log (Pick 3 Evening Price) & $\begin{array}{c}-0.179 * * * \\
(0.044)\end{array}$ & $\begin{array}{c}-0.220 * * * \\
(0.035)\end{array}$ \\
\hline Log (Pick 4 Evening Price) & $\begin{array}{l}0.105 * * * \\
(0.041) \\
\end{array}$ & $\begin{array}{c}0.039 \\
(0.034) \\
\end{array}$ \\
\hline $\begin{array}{l}\text { Dummy Variable for Day After a Green Ball is } \\
\text { Drawn }\end{array}$ & $\begin{array}{c}0.024 * * \\
(0.012)\end{array}$ & $\begin{array}{c}0.033 * * * \\
(0.010) \\
\end{array}$ \\
\hline Dummy Variable for Day After a Red Ball is Drawn & $\begin{array}{c}-0.029 * * \\
(0.012)\end{array}$ & $\begin{array}{c}-0.026 * * * \\
(0.008) \\
\end{array}$ \\
\hline $\begin{array}{l}\text { Dummy Variable for the first } 75 \text { days after the end } \\
\text { of a Green Ball Promotion }\end{array}$ & $\begin{array}{c}0.062 * * * \\
(0.010) \\
\end{array}$ & $\begin{array}{c}0.058 * * * \\
(0.006) \\
\end{array}$ \\
\hline $\begin{array}{l}75 \text { Minus Number of Days after Green Ball } \\
\text { Promotion (for } 75 \text { days) }\end{array}$ & $\begin{array}{c}0.001 * * * \\
(0.000) \\
\end{array}$ & $\begin{array}{c}0.001 * * * \\
(0.000) \\
\end{array}$ \\
\hline $\begin{array}{l}\text { Dummy Variable for the first } 75 \text { days after the end } \\
\text { of a Red Ball Promotion }\end{array}$ & $\begin{array}{l}-0.033 * \\
(0.019) \\
\end{array}$ & $\begin{array}{l}-0.016 \\
(0.013) \\
\end{array}$ \\
\hline $\begin{array}{l}75 \text { Minus Number of Days after Red Ball Promotion } \\
\text { (for } 75 \text { days) }\end{array}$ & $\begin{array}{l}-4.48 \mathrm{E}-04 \\
(3.68 \mathrm{E}-04)\end{array}$ & $\begin{array}{l}-1.14 \mathrm{E}-04 \\
(2.38 \mathrm{E}-04)\end{array}$ \\
\hline First 5 Days of the Month Dummy & $\begin{array}{c}0.013 * * \\
(0.006)\end{array}$ & $\begin{array}{c}0.026 * * * \\
(0.004) \\
\end{array}$ \\
\hline Last 5 Days of the Month Dummy & $\begin{array}{l}-0.008 \\
(0.006) \\
\end{array}$ & $\begin{array}{c}-0.007 * \\
(0.004) \\
\end{array}$ \\
\hline Monday Dummy & $\begin{array}{c}0.193 * * * \\
(0.006) \\
\end{array}$ & $\begin{array}{c}0.181 * * * \\
(0.005) \\
\end{array}$ \\
\hline Tuesday Dummy & $\begin{array}{c}0.160 * * * \\
(0.006) \\
\end{array}$ & $\begin{array}{c}0.147 * * * \\
(0.005) \\
\end{array}$ \\
\hline Wednesday Dummy & $\begin{array}{c}0.176^{* * * *} \\
(0.007) \\
\end{array}$ & $\begin{array}{c}0.158 * * * \\
(0.006) \\
\end{array}$ \\
\hline Thursday Dummy & $\begin{array}{c}0.234 * * * \\
(0.006) \\
\end{array}$ & $\begin{array}{l}0.222 * * * \\
(0.005) \\
\end{array}$ \\
\hline Friday Dummy & $\begin{array}{c}0.234 * * * \\
(0.006) \\
\end{array}$ & $\begin{array}{c}0.252^{* * * *} \\
(0.005)\end{array}$ \\
\hline Saturday Dummy & $\begin{array}{c}0.214^{* * * *} \\
(0.005)\end{array}$ & $\begin{array}{c}0.205^{* * *} * \\
(0.005)\end{array}$ \\
\hline Log(Mega Millions jackpot in millions) & $\begin{array}{c}4.51 \mathrm{E}-04 \\
(3.90 \mathrm{E}-03)\end{array}$ & $\begin{array}{c}0.003 \\
(0.002)\end{array}$ \\
\hline
\end{tabular}




\begin{tabular}{|c|c|c|}
\hline NJ Unemployment Rate SA & $\begin{array}{c}-0.040 * * * \\
(0.006) \\
\end{array}$ & $\begin{array}{c}-0.028 * * * \\
(0.004) \\
\end{array}$ \\
\hline Log(Average Daily Gas Price) & $\begin{array}{c}-0.099 * * * \\
(0.029)\end{array}$ & $\begin{array}{c}-0.080 * * * \\
(0.018)\end{array}$ \\
\hline Daily Precipitation in Newark & $\begin{array}{c}-0.020 * * * \\
(0.004)\end{array}$ & $\begin{array}{c}-0.020 * * * \\
(0.004)\end{array}$ \\
\hline New Year's Day Dummy & $\begin{array}{c}-0.205^{* *} \\
(0.080)\end{array}$ & $\begin{array}{c}-0.185^{* *} \\
(0.079)\end{array}$ \\
\hline Day Before New Year's Day Dummy & $\begin{array}{l}-0.009 \\
(0.049)\end{array}$ & $\begin{array}{c}-0.023 \\
(0.046)\end{array}$ \\
\hline Day After New Year's Day Dummy & $\begin{array}{c}0.007 \\
(0.038)\end{array}$ & $\begin{array}{c}0.041 \\
(0.039)\end{array}$ \\
\hline Martin Luther King Holiday Dummy & $\begin{array}{c}-0.115^{* * *} * \\
(0.041)\end{array}$ & $\begin{array}{c}-0.092 * * * \\
(0.026)\end{array}$ \\
\hline Day Before Martin Luther King Holiday Dummy & $\begin{array}{c}-0.122 * \\
(0.064) \\
\end{array}$ & $\begin{array}{c}-0.083^{* *} \\
(0.033) \\
\end{array}$ \\
\hline Day After Martin Luther King Holiday Dummy & $\begin{array}{c}-0.080 * * \\
(0.038)\end{array}$ & $\begin{array}{c}-0.064 * * \\
(0.027) \\
\end{array}$ \\
\hline Lincoln's Birthday Holiday Dummy & $\begin{array}{c}0.030 \\
(0.022)\end{array}$ & $\begin{array}{c}0.035 * * \\
(0.015)\end{array}$ \\
\hline Day Before Lincoln's Birthday Holiday Dummy & $\begin{array}{c}0.042 \\
(0.030) \\
\end{array}$ & $\begin{array}{l}0.044 * \\
(0.024)\end{array}$ \\
\hline Day After Lincoln's Birthday Holiday Dummy & $\begin{array}{c}0.031 \\
(0.027)\end{array}$ & $\begin{array}{l}0.035 * \\
(0.020)\end{array}$ \\
\hline Washington's Birthday Holiday Dummy & $\begin{array}{l}-0.003 \\
(0.016) \\
\end{array}$ & $\begin{array}{l}-0.007 \\
(0.016) \\
\end{array}$ \\
\hline Day Before Washington's Birthday Holiday Dummy & $\begin{array}{c}0.043 * * \\
(0.017)\end{array}$ & $\begin{array}{c}0.040 * * * \\
(0.012)\end{array}$ \\
\hline Day After Washington's Birthday Holiday Dummy & $\begin{array}{c}0.054 * * * \\
(0.012)\end{array}$ & $\begin{array}{c}0.047 * * * \\
(0.012)\end{array}$ \\
\hline Good Friday Holiday Dummy & $\begin{array}{c}0.043 \\
(0.030)\end{array}$ & $\begin{array}{c}0.013 \\
(0.016)\end{array}$ \\
\hline Day Before Good Friday Holiday Dummy & $\begin{array}{c}0.076 * * * \\
(0.020)\end{array}$ & $\begin{array}{c}0.053 * * * \\
(0.016)\end{array}$ \\
\hline Day After Good Friday Holiday Dummy & $\begin{array}{c}0.086 * * \\
(0.043)\end{array}$ & $\begin{array}{c}0.059 * * \\
(0.025\end{array}$ \\
\hline Memorial Day Holiday Dummy & $\begin{array}{c}-0.245^{* * *} * \\
(0.011)\end{array}$ & $\begin{array}{c}-0.218 * * * \\
(0.007)\end{array}$ \\
\hline Day Before Memorial Day Holiday Dummy & $\begin{array}{c}0.005 \\
(0.012) \\
\end{array}$ & $\begin{array}{c}-0.013 \\
(0.008) \\
\end{array}$ \\
\hline Day After Memorial Day Holiday Dummy & $\begin{array}{c}-0.028 * * * \\
(0.008)\end{array}$ & $\begin{array}{c}-0.033 * * * \\
(0.010)\end{array}$ \\
\hline Independence Day Holiday Dummy & $\begin{array}{l}-0.108 \\
(0.074)\end{array}$ & $\begin{array}{c}-0.113^{* *} \\
(0.057)\end{array}$ \\
\hline Day Before Independence Day Holiday Dummy & $\begin{array}{c}0.001 \\
(0.032)\end{array}$ & $\begin{array}{c}-0.005 \\
(0.021)\end{array}$ \\
\hline Day After Independence Day Holiday Dummy & $\begin{array}{c}-0.066 \\
(0.064)\end{array}$ & $\begin{array}{c}-0.046 \\
(0.057)\end{array}$ \\
\hline Labor Day Holiday Dummy & $\begin{array}{c}-0.192 * * * \\
(0.017)\end{array}$ & $\begin{array}{c}-0.176^{* * * *} \\
(0.013)\end{array}$ \\
\hline Day Before Labor Day Holiday Dummy & $\begin{array}{l}0.029 * \\
(0.016)\end{array}$ & $\begin{array}{c}0.003 \\
(0.015)\end{array}$ \\
\hline
\end{tabular}




\begin{tabular}{|c|c|c|}
\hline Day After Labor Day Holiday Dummy & $\begin{array}{c}0.009 \\
(0.013) \\
\end{array}$ & $\begin{array}{c}-0.001 \\
(0.012) \\
\end{array}$ \\
\hline Columbus Day Holiday Dummy & $\begin{array}{c}-0.050^{* * * *} \\
(0.012)\end{array}$ & $\begin{array}{c}-0.048 * * * \\
(0.008)\end{array}$ \\
\hline Day Before Columbus Day Holiday Dummy & $\begin{array}{l}-0.015 \\
(0.014)\end{array}$ & $\begin{array}{l}-0.015 \\
(0.011)\end{array}$ \\
\hline Day After Columbus Day Holiday Dummy & $\begin{array}{c}-0.031 * * * \\
(0.011) \\
\end{array}$ & $\begin{array}{c}-0.024 * * * \\
(0.008)\end{array}$ \\
\hline Election Day Dummy & $\begin{array}{c}0.013 \\
(0.019) \\
\end{array}$ & $\begin{array}{c}0.030 * * \\
(0.012 \\
\end{array}$ \\
\hline Day Before Election Day Dummy & $\begin{array}{l}-0.006 \\
(0.016) \\
\end{array}$ & $\begin{array}{c}0.002 \\
(0.013) \\
\end{array}$ \\
\hline Day After Election Day Dummy & $\begin{array}{c}-0.006 \\
(0.018) \\
\end{array}$ & $\begin{array}{c}0.010 \\
(0.013) \\
\end{array}$ \\
\hline Veterans Day Holiday Dummy & $\begin{array}{c}-0.029 * * \\
(0.014)\end{array}$ & $\begin{array}{c}-0.029 * * * \\
(0.010)\end{array}$ \\
\hline Day Before Veterans Day Holiday Dummy & $\begin{array}{c}-0.036 * * \\
(0.017) \\
\end{array}$ & $\begin{array}{c}-0.031 * * * \\
(0.012) \\
\end{array}$ \\
\hline Day After Veterans Day Holiday Dummy & $\begin{array}{l}-0.007 \\
(0.012) \\
\end{array}$ & $\begin{array}{l}-0.010 \\
(0.013) \\
\end{array}$ \\
\hline Thanksgiving Day Holiday Dummy & $\begin{array}{c}-0.331 * * * \\
(0.013) \\
\end{array}$ & $\begin{array}{c}-0.305 * * * \\
(0.013) \\
\end{array}$ \\
\hline Day Before Thanksgiving Day Holiday Dummy & $\begin{array}{c}-0.083^{* * * *} \\
(0.018) \\
\end{array}$ & $\begin{array}{c}-0.095 * * * \\
(0.014)\end{array}$ \\
\hline Day After Thanksgiving Day Holiday Dummy & $\begin{array}{c}0.052 * * * \\
(0.008)\end{array}$ & $\begin{array}{c}0.072 * * * \\
(0.010) \\
\end{array}$ \\
\hline Trend & $\begin{array}{c}2.08 \mathrm{E}-04 * * * \\
(1.41 \mathrm{E}-05)\end{array}$ & $\begin{array}{c}1.38 \mathrm{E}-04 * * * \\
(9.05 \mathrm{E}-06)\end{array}$ \\
\hline $\operatorname{AR}(1)$ & $\begin{array}{c}0.541 * * * \\
(0.056)\end{array}$ & $\begin{array}{c}0.385 * * * \\
(0.068)\end{array}$ \\
\hline R-squared & 0.780 & 0.789 \\
\hline Adjusted R-squared & 0.773 & 0.782 \\
\hline F-Statistic & 102.5 & 108.3 \\
\hline Durbin-Watson statistic & 2.12 & 1.74 \\
\hline
\end{tabular}

***Statistically significant at the .01 level; $* *$ Statistically significant at the .05 level; $*$ Statistically significant at the .10 level. Robust standard errors in parentheses. 
Table 8

Percentage change in sales due to statistically significant non-holiday dummy variables*

\begin{tabular}{|l|r|r|}
\hline & $\begin{array}{c}\frac{\text { MODEL 5 }}{\text { Percentage }} \\
\text { Change in } \\
\text { Instant } \\
\text { Games Sales }\end{array}$ & $\begin{array}{c}\frac{\text { MODEL 6 }}{\text { Percentage }} \\
\text { Change in Sales } \\
\text { of all Pick 3 + } \\
\text { all Pick 4 + } \\
\text { Instant }\end{array}$ \\
\hline $\begin{array}{l}\text { Dummy Variable for Day After a Green Ball } \\
\text { is Drawn }\end{array}$ & $2.4 \%$ & $3.4 \%$ \\
\hline $\begin{array}{l}\text { Dummy Variable for Day After a Red Ball is } \\
\text { Drawn }\end{array}$ & $-2.9 \%$ & $-2.6 \%$ \\
\hline $\begin{array}{l}\text { Dummy Variable for the first 75 days after the } \\
\text { end of a Green Ball Promotion }\end{array}$ & $6.4 \%$ & $6.0 \%$ \\
\hline $\begin{array}{l}\text { Dummy Variable for the first 75 days after the } \\
\text { end of a Red Ball Promotion }\end{array}$ & & \\
\hline First 5 Days of the Month Dummy & $1.3 \%$ & $2.6 \%$ \\
\hline Last 5 Days of the Month Dummy & $21.3 \%$ & $19.8 \%$ \\
\hline Monday Dummy & $17.4 \%$ & $15.8 \%$ \\
\hline Tuesday Dummy & $19.2 \%$ & $17.1 \%$ \\
\hline Wednesday Dummy & $26.4 \%$ & $24.9 \%$ \\
\hline Thursday Dummy & $26.4 \%$ & $28.7 \%$ \\
\hline Friday Dummy & $23.9 \%$ & $22.8 \%$ \\
\hline Saturday Dummy & & \\
\hline
\end{tabular}

*We only include statistically significant variables at the $95 \%$ confidence level here.

Note: These percentage changes were calculated as $\left(\mathbb{C}\left(e^{D}-1\right) * \mathbf{1 0 0}\right)$, where $B$ is the dummy coefficient from the semilogarithmic regression, where sales are in logs and the regressor is a binary dummy variable. 
Table 9

Percentage change in sales due to statistically significant holiday dummy variables*

\begin{tabular}{|c|c|c|}
\hline & $\begin{array}{l}\text { MODEL 5 } \\
\text { Percentage } \\
\text { Change in } \\
\text { Instant Games } \\
\text { Sales }\end{array}$ & $\begin{array}{c}\text { MODEL 6 } \\
\text { Percentage Change } \\
\text { in Sales of all Pick } 3 \\
+ \text { all Pick } 4+ \\
\text { Instant }\end{array}$ \\
\hline New Year's Day Dummy & $-18.5 \%$ & $-16.9 \%$ \\
\hline \multicolumn{3}{|l|}{ Day Before New Year's Day Dummy } \\
\hline \multicolumn{3}{|l|}{ Day After New Year's Day Dummy } \\
\hline Martin Luther King Holiday Dummy & $-10.9 \%$ & $-8.8 \%$ \\
\hline Day Before Martin Luther King Holiday Dummy & & $-8.0 \%$ \\
\hline Day After Martin Luther King Holiday Dummy & $-7.7 \%$ & $-6.2 \%$ \\
\hline Lincoln's Birthday Holiday Dummy & & $3.6 \%$ \\
\hline \multicolumn{3}{|l|}{ Day Before Lincoln's Birthday Holiday Dummy } \\
\hline \multicolumn{3}{|l|}{ Day After Lincoln's Birthday Holiday Dummy } \\
\hline \multicolumn{3}{|l|}{ Washington's Birthday Holiday Dummy } \\
\hline Day Before Washington's Birthday Holiday Dummy & $4.4 \%$ & $4.1 \%$ \\
\hline Day After Washington's Birthday Holiday Dummy & $5.5 \%$ & $4.8 \%$ \\
\hline \multicolumn{3}{|l|}{ Good Friday Holiday Dummy } \\
\hline Day Before Good Friday Holiday Dummy & $7.9 \%$ & $5.4 \%$ \\
\hline Day After Good Friday Holiday Dummy & $9.0 \%$ & $6.1 \%$ \\
\hline Memorial Day Holiday Dummy & $-21.7 \%$ & $-19.6 \%$ \\
\hline \multicolumn{3}{|l|}{ Day Before Memorial Day Holiday Dummy } \\
\hline Day After Memorial Day Holiday Dummy & $-2.8 \%$ & $-3.2 \%$ \\
\hline Independence Day Holiday Dummy & & $-10.7 \%$ \\
\hline \multicolumn{3}{|l|}{ Day Before Independence Day Holiday Dummy } \\
\hline \multicolumn{3}{|l|}{ Day After Independence Day Holiday Dummy } \\
\hline Labor Day Holiday Dummy & $-17.5 \%$ & $-16.1 \%$ \\
\hline \multicolumn{3}{|l|}{ Day Before Labor Day Holiday Dummy } \\
\hline \multicolumn{3}{|l|}{ Day After Labor Day Holiday Dummy } \\
\hline Columbus Day Holiday Dummy & $-4.9 \%$ & $-4.7 \%$ \\
\hline \multicolumn{3}{|l|}{ Day Before Columbus Day Holiday Dummy } \\
\hline Day After Columbus Day Holiday Dummy & $-3.1 \%$ & $-2.4 \%$ \\
\hline Election Day Dummy & & $3.0 \%$ \\
\hline \multicolumn{3}{|l|}{ Day Before Election Day Dummy } \\
\hline \multicolumn{3}{|l|}{ Day After Election Day Dummy } \\
\hline Veterans Day Holiday Dummy & $-2.9 \%$ & $-2.9 \%$ \\
\hline Day Before Veterans Day Holiday Dummy & $-3.5 \%$ & $-3.1 \%$ \\
\hline \multicolumn{3}{|l|}{ Day After Veterans Day Holiday Dummy } \\
\hline Thanksgiving Day Holiday Dummy & $-28.2 \%$ & $-26.3 \%$ \\
\hline Day Before Thanksgiving Day Holiday Dummy & $-8.0 \%$ & $-9.1 \%$ \\
\hline Day After Thanksgiving Day Holiday Dummy & $5.3 \%$ & $7.5 \%$ \\
\hline
\end{tabular}

*We only include statistically significant variables at the $95 \%$ confidence level here.

Note: These percentage changes were calculated as $\left.\left(G(e]^{B}-1\right) * \mathbf{1 0 0}\right)$, where $B$ is the dummy coefficient from the semilogarithmic regression, where sales are in logs and the regressor is a binary dummy variable. 


\footnotetext{
${ }^{1}$ See Grote and Matheson [2011] for additional references on price elasticities of large jackpot lottery games.

${ }^{2}$ For example, the Ohio Lottery has used a Red Ball promotion for its Pick 3 game that starts with six white balls and one Red Ball. In contrast to the New Jersey Lottery, the Ohio promotion is less generous to players as prizes are increased only 20\% when the Red Ball is drawn. The Tennessee Lottery has used a Green Ball promotion for its Cash 3 game that starts with ten white balls and one Green Ball. Tennessee increases Cash 3 prizes $20 \%$ when its Pick 3 Green Ball is drawn. The Pennsylvania Lottery has run a "Shamrock Bonus Week" during the week including St. Patrick's Day in which evening daily numbers games prizes are increased $10 \%$ if a Green Ball is drawn or 20\% if a shamrock ball is drawn. Finally, the Illinois Lottery has operated Green Ball promotions for its Pick 3 game where two sets of winning numbers are drawn when a Green Ball is selected. These Illinois promotions start with nine white balls and one Green Ball.

${ }^{3}$ Daily sales data are unavailable for the Mega Millions and Pick 6 lotto games, because sales for these games are recorded only twice per week to correspond with their twice-weekly drawings. The unavailability of daily data led to problems estimating the demand for these games with respect to the daily prices of Pick 3 and Pick 4 . We also omit Jersey 5 because we could not explain more than about $30 \%$ of the variation in sales. See footnote 20 for more details.

${ }^{4}$ Combs and Spry [2012] estimate the change in income elasticity after the introduction of a midday drawing for Pick 3 and Pick 4 numbers games in Ohio. They also give an estimate of the price elasticity of Pick 3 using data from episodic Red Ball promotions for the Pick 3 game. However, this is a crude estimate of the price elasticity of Pick 3 because their study combines data from a week's worth of individual drawings and uses weekly sales rather than daily sales, and computes average weekly prices rather than daily prices. In addition, Ohio did not introduce a Pick 4 promotion so no Pick 4 own-price elasticity could be estimated in Ohio.

${ }^{5}$ The New Jersey fiscal year runs from July 1 to June 30 of the following year.

${ }^{6}$ Source: http://www.state.nj.us/lottery/index.shtml. The New Jersey Lottery pays out a higher percentage of money wagered on straight bets than on other bets. Terrell [1994] reports that for straight bets in the Pick 3 game, the New Jersey Lottery "places 52\% of all money bet in the game into the payout pool to be split equally among all bettors choosing the correct number."

${ }^{7}$ When the numbers 5-8-7 were drawn the evening of November 12, 2001 after American Airlines Flight 587 crashed earlier that day, the winning 50 cent straight bet on the tragic numbers 5-8-7 paid only $\$ 16$, the smallest payment in the history of the New Jersey Lottery Pick 3 game, because 27,829 straight bets were placed on that number. The previous time 5-8-7 were the winning numbers, the prize for a straight $\$ 0.50$ bet was $\$ 290.50$. When 7-7-7 was drawn on December 21, 1988, the winning prize for a straight $\$ 0.50$ bet was only $\$ 63.50$.

8 “The Federal Energy Policy Act of 1992, section 1942, requires the New Jersey Lottery to withhold a minimum $25 \%$ of all prize payments to any Lottery winner who has won more than $\$ 5,000$ on any Lottery wager. At the end of the year, the winner will receive a W2-G form to properly credit the withholding as a tax payment on their federal income tax form. Winners who do not possess a social security number are subject to a $30 \%$ federal income tax deduction on any prize over $\$ 599.50$. Under the provisions of P.L. 2009, c.69, as of January 1, 2009, the New Jersey Lottery is required to withhold 3\% State taxes from all Lottery winnings over $\$ 10,000$." Source: http://www.state.nj.us/lottery/home.shtml.

${ }^{9}$ During the Green Ball promotions, the New Jersey Lottery started with five or six white balls, depending on the year. The promotion is more generous when it begins with a smaller number of white balls, as this increases the odds of prize payments during the promotion period. The first Green Ball promotion in our sample ran from March 7, 2005 until March 29, 2005 with five white balls and one Green Ball. The rest of the Green Ball promotions were run with six white balls and one Green Ball from February 6, 2006 until March 5, 2006; February 19, 2007 until March 18, 2007; March 3, 2008 until March 30, 2008; and March 2, 2009 until March 29, 2009.

${ }^{10}$ The Red Ball promotion was held October 30, 2006 until November 26, 2006; August 6, 2007 until September 2 2007; and October 13, 2008 until November 9, 2008.

${ }^{11}$ The New Jersey Lottery issues press releases related to its Green and Red Ball promotions so that consumers are aware of when they are running. Although the number of white balls left in the hopper is not reported in media outlets on a daily basis, colored ball drawings are reported. These media outlets include the New Jersey Lottery website, the New Jersey Network (local cable television), local news television on major networks/websites, and newspapers such as The Jersey Journal, The Trenton Times, and The Star-Ledger.

${ }^{12}$ The New Jersey Lottery has a monopoly in the New Jersey market for lottery tickets. Therefore, there is no supply curve for this market.
} 
${ }^{13}$ It is important to note that since the New Jersey Lottery has decided to run Green Ball and Red Ball promotions only during the evening drawings, the expected value of a purchase of a $\$ 1.00$ midday Pick 3 or Pick 4 lottery ticket remains $\$ 0.50$ at all times.

${ }^{14}$ The New Jersey Lottery only makes statewide sales data available; individual retailer and smaller geographical unit sales data are not publically available. Additional information about New Jersey Pick 3 and Pick 4 games and rules is available at the New Jersey Lottery Website: http://www.state.nj.us/lottery/index.shtml.

${ }^{15}$ The AR(1) specification forces the estimated short- and long-run price elasticities to be equal, according to Cuddington and Dagher [2011, p. 11].

${ }^{16}$ We examined the pattern of the average level of a game's sales for each day after that game's promotion had ended. We found that this average level of a game's sales after the promotion was relatively high the first day after a promotion ended, and declined thereafter, for at least 75 days after the promotion ended. We used 75 days to define our lag period because the spillover effect persisted at least that long, and we wanted to make sure that the lag period ended before the next promotion. The minimum amount of time between promotions was 85 days.

${ }_{17}^{17}$ See http://lwd.dol.state.nj.us/labor/lpa/pub/emppress/pressrelease/njsa.xls.

${ }^{18}$ New Jersey state holidays include New Year's Day, Martin Luther King Day, Lincoln's and Washington's Birthdays, Good Friday, Memorial Day, Independence Day, Labor Day, Columbus Day, Election Day, Veterans' Day, Thanksgiving, and Christmas Day. Lottery sales take place on all of these holidays except Christmas Day. ${ }^{19}$ For more information, see http://climate.rutgers.edu/stateclim/.

${ }^{20}$ The Mega Millions and Pick 6 Lotto sales and prizes are recorded only twice a week. After interpolating the twice-weekly data to obtain the missing days' sales, our estimates of demand for these two games had extreme serial correlation and a high R-squared, as could be expected. Even so, there was no statistically significant effect of the Red and Green Ball promotions on sales of these large jackpot games. We also estimated the demand for Jersey 5 , but very little of the variation in Jersey 5 sales was explained by the regression (whose adjusted R-squared was around .30), with the Green Ball drawing having no statistically significant effect (at the 95\% confidence level) on Jersey 5 sales. This may indicate missing independent variables for Jersey 5 sales, such as its jackpot size, for which we do not have data.

${ }^{21}$ The augmented Dickey-Fuller unit root test was performed with the standard commands in EViews 6 . We also conducted Phillips-Perron tests for a unit root in the level of the same series and also rejected the null hypothesis of a unit root.

${ }^{22}$ This compares to an own-price elasticity of Pick 3 games of -1.11 obtained from weekly (not daily) data in Combs and Spry [2012].

${ }^{23}$ This compares to a cross-price elasticity of -.51 of Pick 4 sales with respect to the average weekly price of Pick 3 , using weekly (not daily) data [Combs and Spry 2012].

${ }^{24}$ Thanksgiving Day is the fourth Thursday in November.

${ }^{25}$ Because the New Jersey Lottery reports that it has a fixed budget of $\$ 1$ million for annual advertising expenses, there is no additional advertising expense attributable to each promotion (e-mail correspondence from New Jersey Lottery, May 23, 2012). 